Article

\title{
Synthesis and Antimicrobial Evaluation of Novel Pyrazolopyrimidines Incorporated with Mono- and Diphenylsulfonyl Groups
}

\author{
Amani M. R. Alsaedi ${ }^{1}$, Thoraya. A. Farghaly ${ }^{2, *(\mathbb{D})}$ and Mohamed R. Shaaban ${ }^{1,2, *}$ \\ 1 Department of Chemistry, Faculty of Applied Science, Umm Al-Qura University, \\ Makkah Almukaramah 21514, Saudi Arabia; ams_ksa85@hotmail.com \\ 2 Department of Chemistry, Faculty of Science, Cairo University, Giza 12613, Egypt \\ * Correspondence: thoraya-f@hotmail.com (T.A.F.); mrgenidi@uqu.edu.sa (M.R.S.); \\ Tel.: +966-545917568 (M.R.S.)
}

Received: 30 September 2019; Accepted: 31 October 2019; Published: 5 November 2019 updates

\begin{abstract}
A novel series of pyrazolo[1,5-a]pyrimidine ring systems containing phenylsulfonyl moiety have been synthesized via the reaction of 2-(phenylsulfonyl)-1-(4-(phenylsulfonyl) phenyl)ethan-1-one, 2-benzenesulfonyl-1-(4-benzenesulfonyl-phenyl)-3-dimethylamino-propenone and 3-(dimethylamino)-1-(4-(phenylsulfonyl)phenyl)prop-2-en-1-one each with various substituted aminoazopyrazole derivatives in one pot reaction strategy. The proposed structure as well as the mechanism of their reactions were discussed and proved with all possible spectral data. The results of antimicrobial activities of the new sulfone derivatives revealed that several derivatives showed activity exceeding the activity of reference drug. Contrary to expectations, we found that derivatives containing one sulfone group are more effective against all bacteria and fungi used than those contain two sulfone groups.
\end{abstract}

Keywords: antimicrobial activity; pyrazolopyrimidine; aminopyrazoles; microwaves; structure-activity relationship (SAR)

\section{Introduction}

Pyrazolo[1,5-a]pyrimidine is known to be purine analog that has protruded a vital building block for pharmaceutical drugs. It has several potent biological implementations as antischistosomal, antimetabolites in purine bio-chemical interactions, sedative and antitrypanosomal [1], AMP phosphodiesterase inhibitors [2], anxiolytic [3], benzodiazepine receptor ligands [4], KDR (kinase insert domain receptor) kinase inhibitors [5], HMG-CoA (3-hydroxy-3-methyl-glutaryl-coenzyme A reductase) reductase inhibitors [6], COX-1 (cyclooxygenase-1), COX-2 (cyclooxygenase-2) selective inhibitors [7], HCV (hepatitis C virus) inhibitors [8], serotonin 5-HT6 (5-hydroxytryptamine) receptor antagonists [9], PET (positron emission tomography) tumor imaging agents [10], kinase inhibitors [11], CCR1 (C-C chemokine receptor type 1) antagonists [12], HIV (human immunodeficiency viruses) reverse transcriptase inhibitors [13], and antifungal and antimalarial activities [14]. Many marketed drugs have pyrazolo[1,5-a]pyrimidine nucleus such as indiplon, zaleplon, dorsomorphin, dinaciclib, anagliptin, pyrazophos, lorediplon, and ocinaplon [15] are showed in Figure 1. Another important scaffold is benzene-sulfone moiety which present in several important pharmaceutical and agrochemical molecules due to their distinctive structural and electronic features. As for instance, molecules used as gamma-secretase inhibitors (I) [16], in migraine and prostate cancer, or as the herbicides mesotrione and cafenstrole, all feature aryl sulfone units [17] (Figure 1). Due to the specific physical and chemical properties as well as the biological activities of azobenzene dyes, they have found wide 
applications in the cosmetic, pharmaceutical, dyeing/textile industry, food, and analytical chemistry [18]. Many of these compounds exhibit biomedical activity because they exhibit various properties such as anti-inflammatory activity, antibacterial activity, cell protection, protease inhibitors (enzymes that play functions in many pathological disorders), or have anti-HIV activity [19-21]. Also, it was proved recently that azo-benzene based compounds showed a killing effect on bacteria or fungi through the interaction with their protein receptors, rather than an interaction with membrane [22,23]. On the other hand, the molecular hybridization is specialized with synthesis new compounds from combination of biologically active substances for the production of a new hybrid compound. In several cases, it generates derivatives having effective biological activities more potent than their starting moieties [24].<smiles>CCOC(=O)c1cn2nc(OP(=S)(OCC)OCC)cc2nc1C</smiles>

Pyrazophos

(Fungicide and insecticide)<smiles>CN1CCC[C@H]1Cc1c[nH]c2ccc(CCS(=O)(=O)c3ccccc3)cc12</smiles>

Eletriptan (treatment of migraine)<smiles></smiles>

Blcalutamide

(treatment of prostate cancer)<smiles>CCN(C(C)=O)c1cccc(-c2ccnc3c(C#N)cnn23)c1</smiles>

Zaleplon (Insonmma)<smiles>O=C(c1ccccn1)c1cnn2c(-c3ccncc3)ccnc12</smiles>

Ocinaplon

(Anxiolytic, sedative and anmestic)<smiles>CCNC(=O)n1cnc(S(=O)(=O)c2c(C)cc(C)cc2C)n1</smiles>

Cafenstrole (herbicide)<smiles>O=S(=O)(c1ccccc1)C1(c2cc(F)ccc2F)CCCCC1</smiles>

(I)

(gamma-secretase inhibitors)

Figure 1. Biological activity of some pyrazolopyrimidines and drugs having benzenesulfone moiety.

Inspired by these observations and in resumption of our recent research aiming at the design and synthesis of new bioactive heterocyclic systems [25-31], we are interested herein to design and synthesize of two new series of pyrazolo[1,5-a]pyrimidine derivatives, 8 and 15 (Figure 2), which have one or two arylsulfonyl and an arylazo groups to investigate their antimicrobial activities. The aim of such synthesis is to study the effect of the combination of such scaffold on the activity of these new series, as we expect to generate a potent active drug as an antimicrobial agent. 


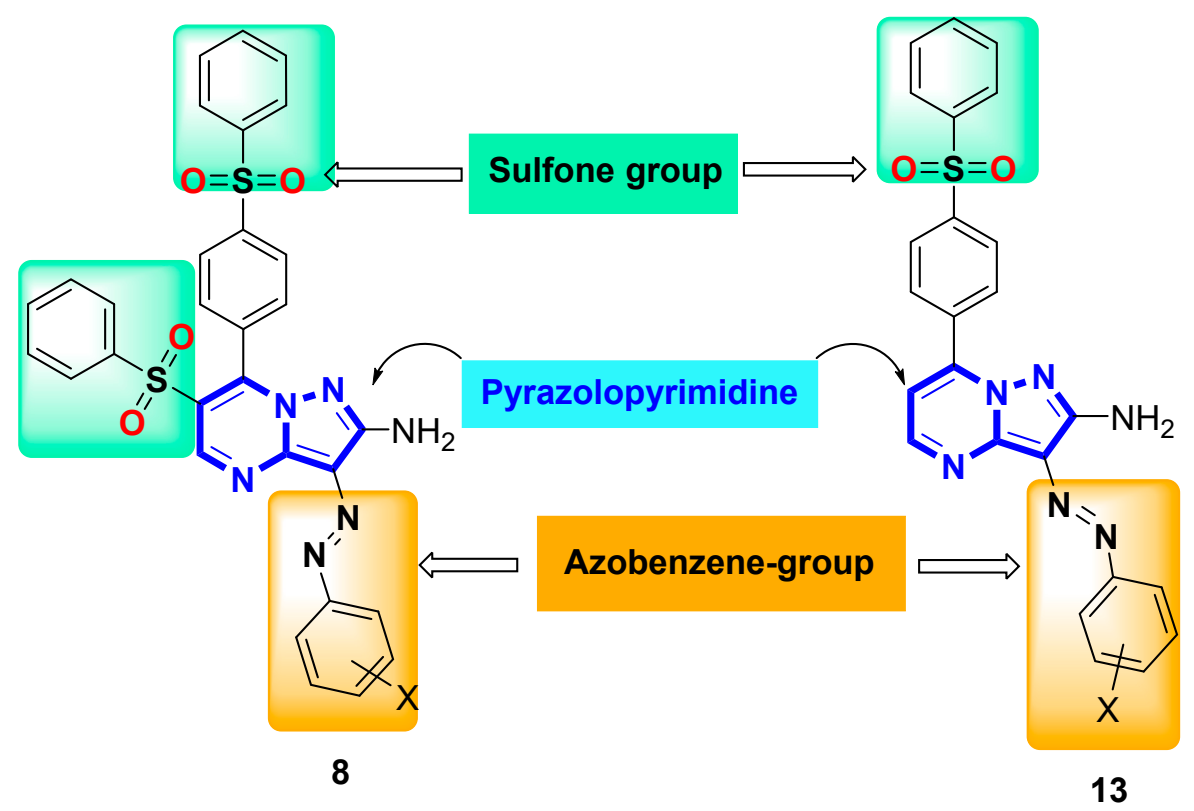

Figure 2. The structure of the new pyrazolopyrimidines $\mathbf{8}$ and $\mathbf{1 3 .}$

\section{Results and Discussion}

\section{Chemistry}

Initially, three consecutive steps were enough to access of the hitherto unreported 3-(dimethylamino)-2-(phenylsulfonyl)-1-(4-(phenylsulfonyl)phenyl)prop-2-en-1-one 6 as a versatile multifunctional building block for construction of the targeted pyrazolo[1,5- $a$ ]pyrimidine derivatives. We started with modified method for $\alpha$-bromination of 1-(4-(phenylsulfonyl)phenyl)ethan-1-one 1 using $\mathrm{N}$-bromosuccinimide (NBS) in the presence of $p$-toluene sulfonic acid $(p$-TsOH) and acetonitrile as a solvent either under thermal or microwaves irradiation conditions (Scheme 1). The $\alpha$-bromoketone 3 was obtained in excellent yield (94\%) under pressurized microwave irradiation (MW) for 15 min using $400 \mathrm{~W}$ microwaves operating power. Then, treatment of compound 3 with sodium benzene sulfinate in ethanol under thermal as well as microwave conditions afforded the corresponding 2-(phenylsulfonyl)-1-(4-(phenylsulfonyl)phenyl)ethan-1-one 4 in high yield (Scheme 1). The suggested structure of compound 4 as illustrated in Scheme 1 was confirmed from its spectral data. The IR spectrum of compound 4 showed the carbonyl absorption signal vibrating at $1700 \mathrm{~cm}^{-1}$. The ${ }^{1} \mathrm{H}$ NMR spectrum of compound 4 displayed the characteristic signal of the $\mathrm{CH}_{2}$ group which clearly appeared at $\delta$ $5.39 \mathrm{ppm}$ in addition to the other protons that are resonating at their expected values (see experimental part). Further evidence that confirm the structure of compound 4 was supported from its ${ }^{13} \mathrm{C}$ NMR which revealed fourteen carbon signals resonating at $\delta$ values as follows: $62.6\left(\mathrm{CH}_{2}\right), 127.6,127.7,128.1$, 129.2, 130.0, 130.2, 134.1, 134.3, 139.1, 139.2, 140.2, 145.3 (12 Ar-C), and 188.6 (C=O) ppm.

Thermal or microwaves heating of the 2-(phenylsulfonyl)-1-(4-(phenylsulfonyl)phenyl)ethan-1-one 4 with $N, N$-dimethylformamide-dimethylacetal (DMF-DMA) $\mathbf{5}$ using dry xylene as a solvent, afforded a single product identified as the corresponding 3-(dimethylamino)-2-(phenylsulfonyl)1-(4-(phenylsulfonyl)phenyl)prop-2-en-1-one 6, in high yields (Scheme 2). All spectral data of the formed enaminosulfone 6 were in agreement with the proposed structure. The presence of low frequency of the $\mathrm{C}=\mathrm{O}$ at $1624 \mathrm{~cm}^{-1}$ in the IR spectrum of enaminosulfone 6 confirm its structure which attributed to the conjugation with the aromatic- $\mathrm{C}=\mathrm{C}$ and the $\mathrm{C}=\mathrm{C}$ of the enamine moiety. Also, the ${ }^{1} \mathrm{H}$ NMR spectrum of enaminosulfone 6 clearly displayed two characteristic singlet signals for the two $\mathrm{CH}_{3}$ and $=\mathrm{CH}$ protons at 3.29 and $8.11 \mathrm{ppm}$ in addition to an aromatic multiplets in the region $\delta 7.36-7.99 \mathrm{ppm}$. It is important to notice that the large value of chemical shift of $=\mathrm{CH}$ of enaminone moiety $(\delta=8.11 \mathrm{ppm})$ indicated that enaminone 6 was assigned the $E$-configuration [32]. 
This large value of the trans-H can be attributed to the high deshielding effect of the direct interaction with $\mathrm{SO}_{2}$ group. While, $\mathrm{Z}$-isomer analogous structure was reported to appear at $\delta 6.9 \mathrm{ppm}$ [33].

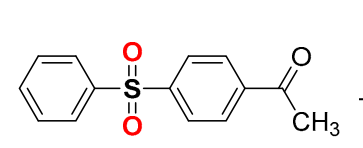

1

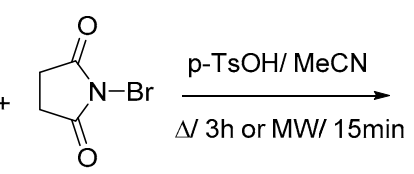

2

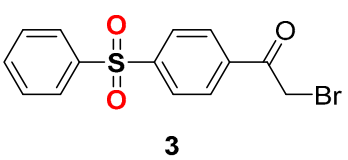

$\Delta$ Yield $=80 \%$ MW Yield $=94 \%$
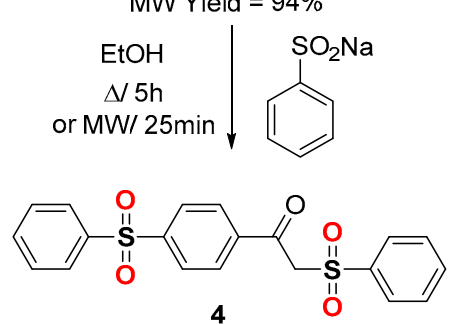

$\Delta$ Yield $=95 \%$

MW Yield $=96 \%$

Scheme 1. Synthesis of compound 4.

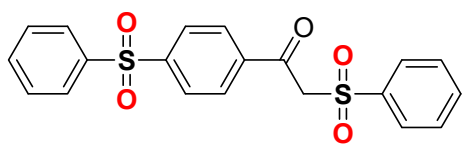

4

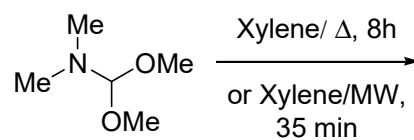

5

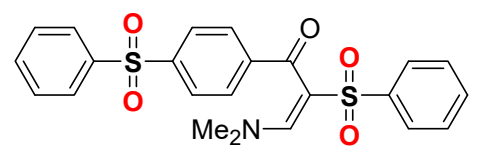

6

$\Delta$ Yield $=83 \%$ MW Yield $=91 \%$

Scheme 2. Synthesis of enaminosulfone 6.

The reaction of the enaminosulfone $\mathbf{6}$ with arylazodiaminopyrazole derivatives $7 \mathbf{a}-\mathbf{h}$ was investigated using two different pathways under thermal and microwaves irradiation conditions. Thus, when enaminosulfone $\mathbf{6}$ was treated with arylazodiaminopyrazoles $7 \mathbf{a}-\mathbf{h}$ in glacial acetic acid, it furnished the corresponding pyrazolopyrimidines derivatives $\mathbf{8 a}-\mathbf{h}$ under thermal as well as microwaves conditions (Scheme 3, Table 1).

Table 1. A comparison between the conventional and microwave heating for the synthesis of compounds $\mathbf{8 a}-\mathbf{h}$.

\begin{tabular}{|c|c|c|c|}
\hline \multirow{2}{*}{ Compound No. } & \multirow{2}{*}{ Ar } & Conventional Heating & Microwave Heating \\
\hline & & Yield\% & Yield\% \\
\hline $8 a$ & $4-\mathrm{ClC}_{6} \mathrm{H}_{4}^{-}$ & 77 & 95 \\
\hline $8 b$ & $3-\mathrm{CH}_{3} \mathrm{C}_{6} \mathrm{H}_{4}^{-}$ & 85 & 95 \\
\hline $8 c$ & $3-\mathrm{ClC}_{6} \mathrm{H}_{4^{-}}$ & 77 & 91 \\
\hline $8 d$ & $2-\mathrm{ClC}_{6} \mathrm{H}_{4}^{-}$ & 78 & 90 \\
\hline $8 \mathrm{e}$ & $3-\mathrm{CH}_{3} \mathrm{OC}_{6} \mathrm{H}_{4}^{-}$ & 80 & 90 \\
\hline $8 f$ & $\mathrm{C}_{6} \mathrm{H}_{5^{-}}^{-}$ & 75 & 90 \\
\hline $8 g$ & $2-\mathrm{NO}_{2} \mathrm{C}_{6} \mathrm{H}_{4^{-}}$ & 90 & 91 \\
\hline $8 \mathrm{~h}$ & $4-\mathrm{CH}_{3} \mathrm{OC}_{6} \mathrm{H}_{4-}^{-}$ & 95 & 95 \\
\hline
\end{tabular}

${ }^{1} \mathrm{H}$ NMR of the isolated pyrazolopyrimidine derivatives gave a strong evidence for the structure 8 rather than 9. The ${ }^{1} \mathrm{H}$ NMR spectra of all derivatives $\mathbf{8} \mathbf{a}-\mathbf{h}$ were characterized with the existence of singlet signal at $\delta$ 9.13-9.23 ppm for the pyrimidine-CH-2 and not $\mathrm{CH}-4$ in structure 9 as shown in Figure 3. The presence of the pyrimidine-CH-2 at $\delta 9.13-9.23$ ppm was confirmed previously by our group via $X$-ray crystallography of the same ring system [34]. 


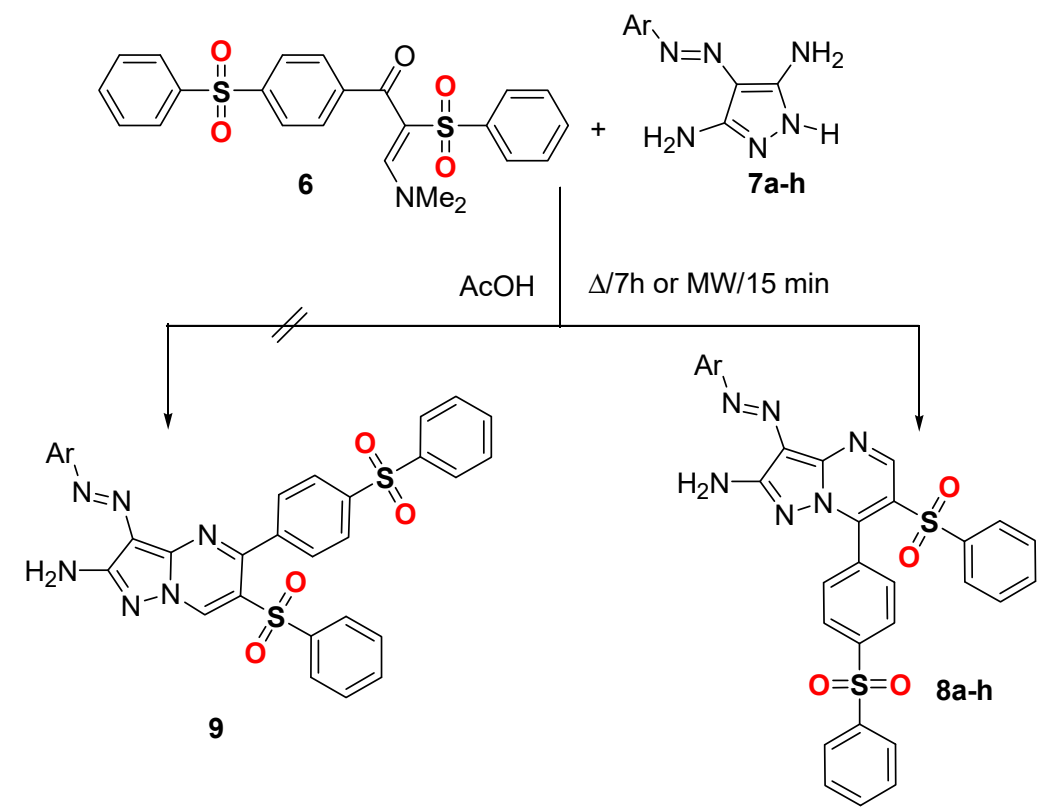

Ar: a, 4- $-\mathrm{ClC}_{6} \mathrm{H}_{4} ; \mathrm{b}, 3-\mathrm{CH}_{3} \mathrm{C}_{6} \mathrm{H}_{4} ; \mathrm{c}, 3-\mathrm{ClC}_{6} \mathrm{H}_{4} ; \mathrm{d}, 2-\mathrm{ClC}_{6} \mathrm{H}_{4}$;

e, $3-\mathrm{CH}_{3} \mathrm{OC}_{6} \mathrm{H}_{4} ; \mathrm{f}, \mathrm{C}_{6} \mathrm{H}_{5} ; \mathrm{g}, 2-\mathrm{NO}_{2} \mathrm{C}_{6} \mathrm{H}_{4} ; \mathrm{h}, 4-\mathrm{CH}_{3} \mathrm{OC}_{6} \mathrm{H}_{4}$
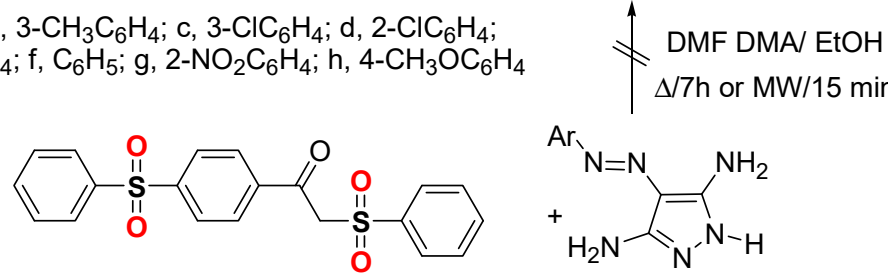
$\Delta / 7 \mathrm{~h}$ or $\mathrm{MW} / 15 \mathrm{~min}$

4

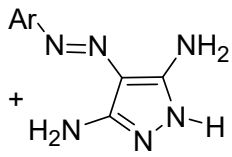

7a-h

Scheme 3. Synthesis of pyrazolopyrimidines $\mathbf{8 a}-\mathbf{h}$.

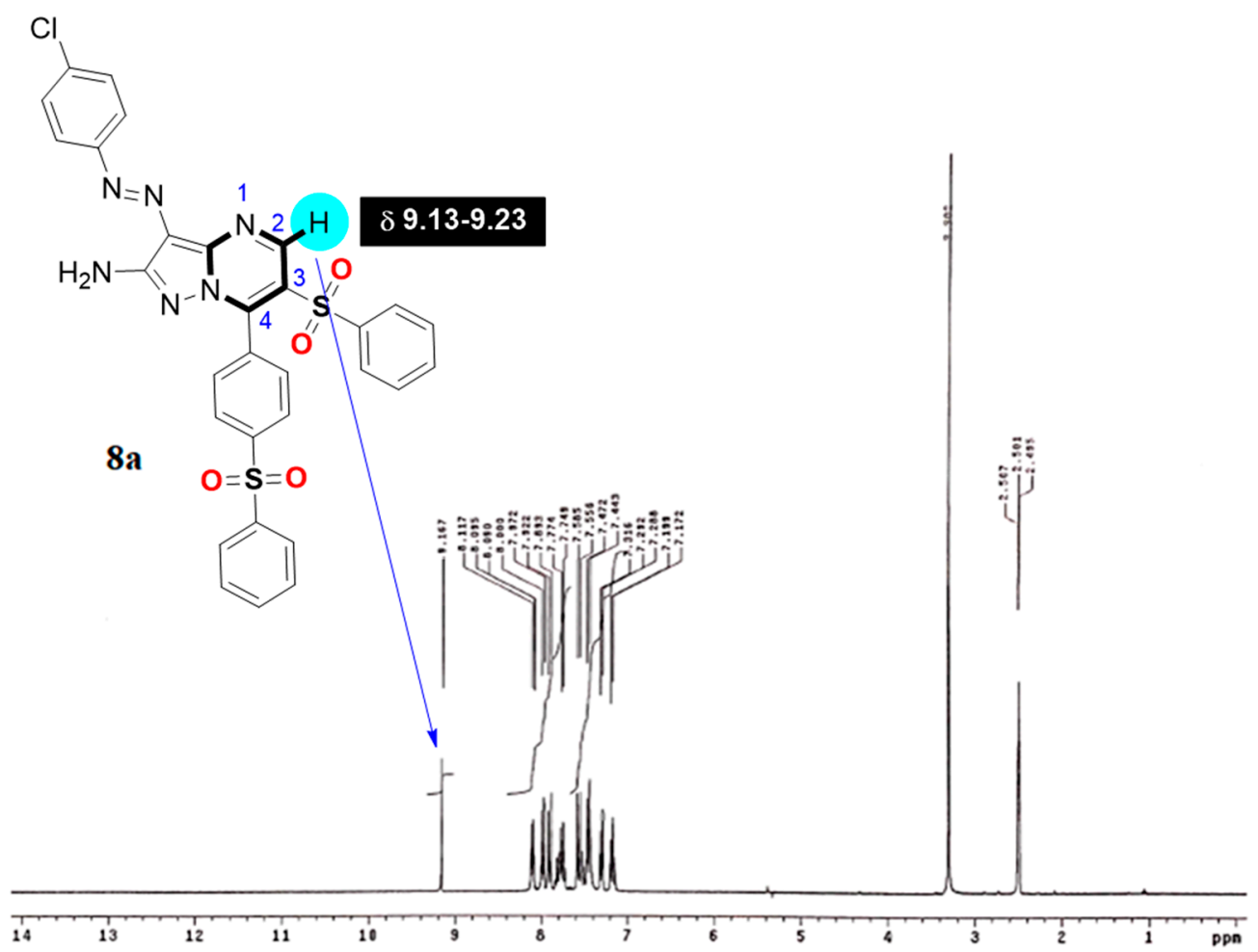

Figure $3 .{ }^{1} \mathrm{H}$ NMR of compound $8 \mathbf{a}$. 
Also, the structure 8 was firmly established for the reaction products by an alternate synthesis. Thus, 2-(phenylsulfonyl)-1-(4-(phenylsulfonyl)phenyl)ethan-1-one 4 was condensed with triethylorthoformate $\mathbf{1 0}$ and subsequent condensation of the formed ethoxymethylene derivative 11 with arylazodiaminopyrazole derivatives $\mathbf{7 a - h}$ gave products identical in all respects (m.p., mixed m.p., and spectra) with those formed from the reaction enaminosulfone 6 with pyrazoles 7 . It should be noted that, multi-components condensation of 2-(phenylsulfonyl)-1-(4-(phenylsulfonyl)-phenyl)ethan-1-one 4, DMF-DMA, and arylazodiaminopyrazole derivatives $\mathbf{7 a}-\mathbf{h}$ have failed to afford the products $\mathbf{8} \mathbf{a}-\mathbf{h}$ as shown in Scheme 3. On the other hand, one pot multi-components condensation of 2-(phenylsulfonyl)-1-(4-(phenylsulfonyl)phenyl)ethan-1-one 4, triethylortho-formate $\mathbf{1 0}$, and arylazodiamino-pyrazoles $\mathbf{7} \mathbf{a}-\mathbf{h}$ afforded the products $\mathbf{8} \mathbf{a}-\mathbf{h}$ as shown in Scheme 4.

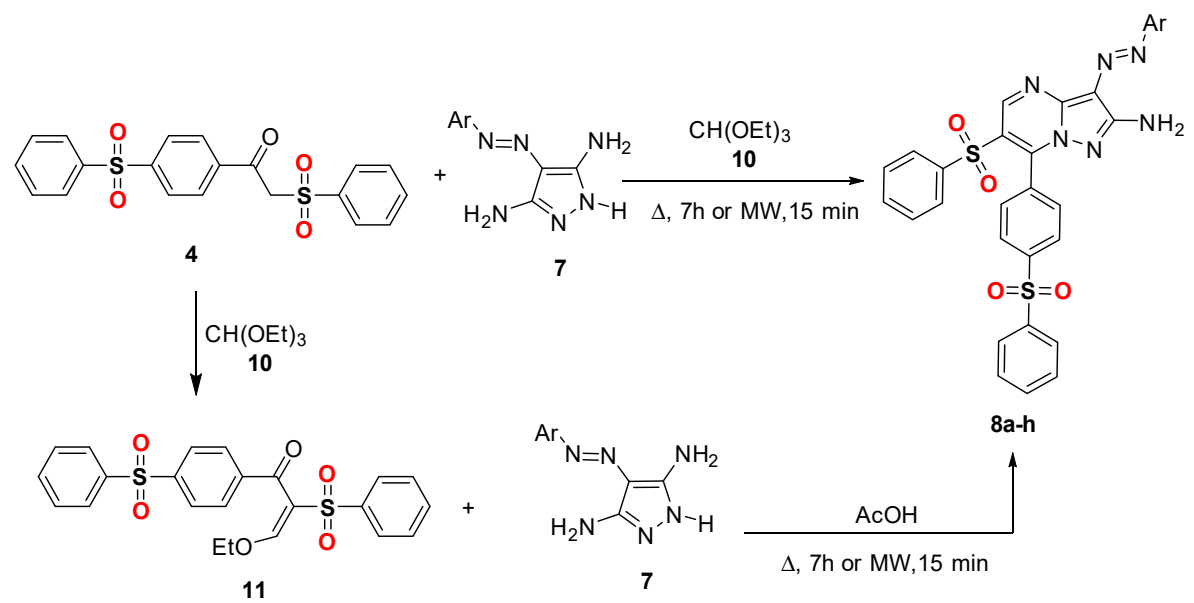

Scheme 4. Alternative synthesis of pyrazolopyrimidines $\mathbf{8 a}-\mathbf{h}$.

In order to examine the influence of phenyl sulfonyl group pendent to pyrimidine ring on the antimicrobial activity, we have decided to synthesize a series of novel pyrazolo[1,5- $a$ ]pyrimidines derivatives 13a-h which have an analogue structure to pyrazolo[1,5-a]pyrimidines derivatives $\mathbf{8 a}-\mathbf{h}$ by exclusion of the phenyl sulfonyl moiety in the pyrimidine ring in the pyrazolo[1,5- $a$ ]pyrimidine ring system. The latter can be achieved via reaction of another enaminosulfone derivative 12 with arylazodiaminopyrazoles $\mathbf{7} \mathbf{a}-\mathbf{h}$ without catalyst in glacial acetic acid under thermal as well as microwave conditions (Scheme 5). The reaction products were identified as the pyrazolo [1,5- $a$ ]pyrimidines derivatives 13a-h and not the isomeric products 14 (Table 2).

Table 2. A comparison between the conventional and microwave heating for the synthesis of compounds 13a-h.

\begin{tabular}{|c|c|c|c|}
\hline \multirow{2}{*}{ Compound No. } & \multirow{2}{*}{ Ar } & Conventional Heating & Microwave Heating \\
\hline & & Yield \% & Yield \% \\
\hline $13 a$ & $4-\mathrm{ClC}_{6} \mathrm{H}_{4}^{-}$ & 92 & 98 \\
\hline $13 b$ & $3-\mathrm{CH}_{3} \mathrm{C}_{6} \mathrm{H}_{4}^{-}$ & 90 & 97 \\
\hline $13 c$ & $3-\mathrm{ClC}_{6} \mathrm{H}_{4^{-}}$ & 90 & 94 \\
\hline $13 d$ & $2-\mathrm{ClC}_{6} \mathrm{H}_{4}^{-}$ & 85 & 97 \\
\hline $13 e$ & $3-\mathrm{CH}_{3} \mathrm{O} \mathrm{C}_{6} \mathrm{H}_{4}-$ & 90 & 93 \\
\hline $13 f$ & $\mathrm{C}_{6} \mathrm{H}_{5^{-}}$ & 80 & 90 \\
\hline $13 \mathrm{~g}$ & $2-\mathrm{NO}_{2} \mathrm{C}_{6} \mathrm{H}_{4}^{-}$ & 92 & 96 \\
\hline $13 \mathrm{~h}$ & $4-\mathrm{CH}_{3} \mathrm{O} \mathrm{C}_{6} \mathrm{H}_{4}^{-}$ & 94 & 98 \\
\hline
\end{tabular}




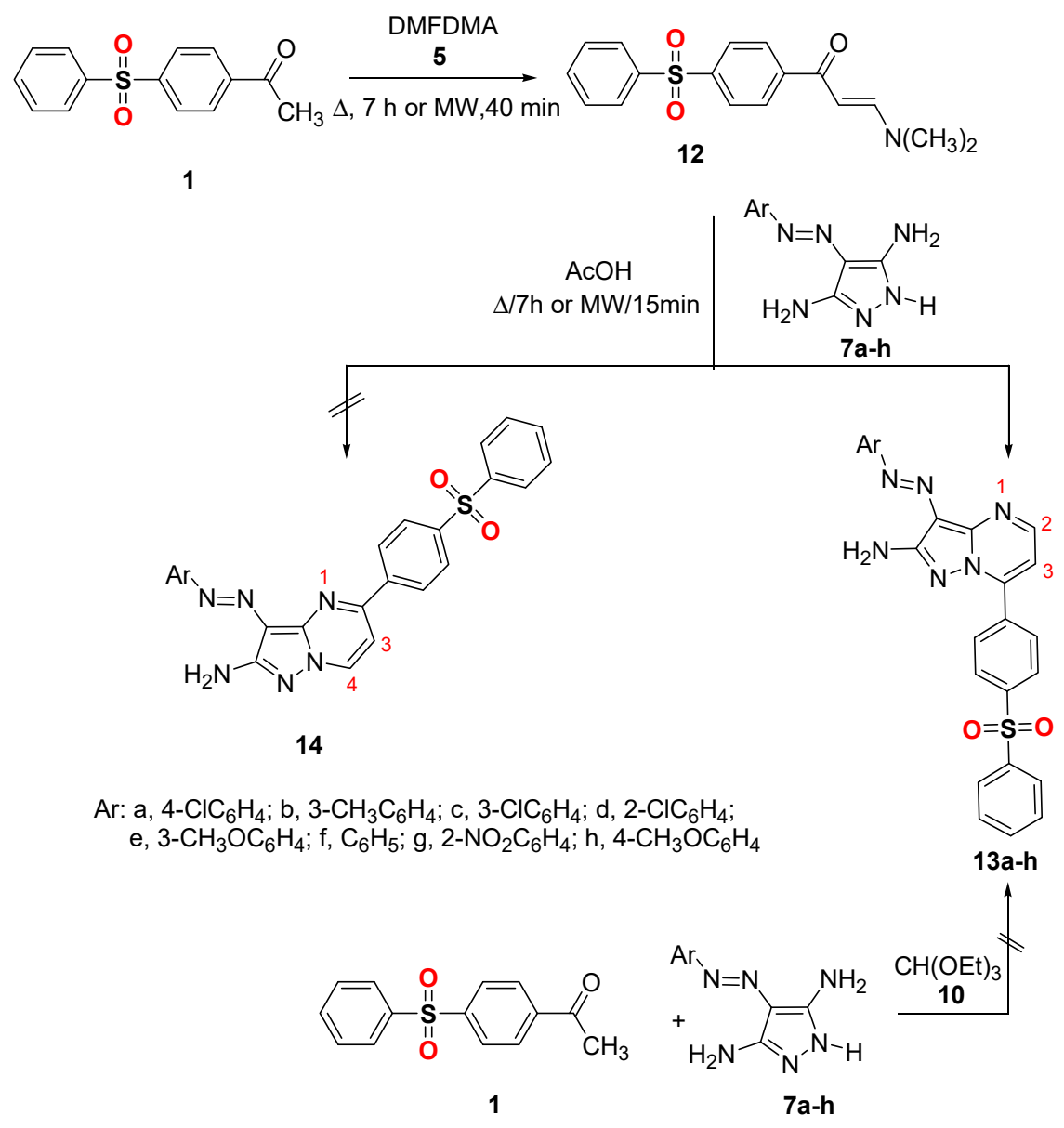

Scheme 5. Synthesis of compounds 13a-h.

The structure of the products $\mathbf{1 3}$ have been confirmed based on spectral data (Figure 4). The structures of the products $\mathbf{1 3} \mathbf{a}-\mathbf{h}$ were established on investigation their spectral data and their elemental analyses. For example, all ${ }^{1} \mathrm{H}$ NMR spectra of derivatives 13a-h revealed two doublet signals $(J \approx 4.5 \mathrm{~Hz})$ near $\delta 7.3$ and 8.8 due to pyrimidine $\mathrm{CH}-3$ and $\mathrm{CH}-2$ protons, respectively. The other expected products 14 were ruled out on the basis of spectral data such as ${ }^{1} \mathrm{H}$ NMR where the $\mathrm{CH}-4$ protons was expected to resonate at low value of chemical shift $\delta$ in their ${ }^{1} \mathrm{H}$ NMR spectrum [35] as well as the literature reports which proved the regioselectivity of such reaction by $\mathrm{X}$-ray crystallographic analysis of the product [32,36].

Attempts to achieve the pyrazolo[1,5-a]pyrimidines derivatives 13a-h via alternative pathway through multicomponent condensation of the acetyl derivative 1, triethylorthoformate 10, and arylazodiaminopyrazoles $\mathbf{7 a} \mathbf{a}-\mathbf{h}$ were not useful in this case (Scheme 5).

From the mechanistic point of view, the multi component synthesis of $\mathbf{8 a}-\mathbf{h}$ was expected to proceed via Michael-type addition in acidic medium of arylazodiaminopyrazoles $7 \mathbf{a}-\mathbf{h}$ to the activated double bond of the ethoxymethylene derivative 11 of 2-(phenylsulfonyl)-1-(4(phenylsulfonyl)phenyl)ethan-1-one 4 followed by loss of ethanol and subsequent intramolecular cyclization via elimination of water to afford the corresponding pyrazolo[1,5-a] pyrimidines derivatives 8a-h, all intermediates were illustrated in Scheme 6. In the same manner and under the same acidic medium, the mechanism of the formation of pyrazolo[1,5-a]pyrimidines derivatives $\mathbf{1 3} \mathbf{a}-\mathbf{h}$ is shown in Scheme 6 which involves Michael type addition followed by cyclocondensation of the non-isolable Michael adduct 18 by loss of dimethylamine to form another three non-isolable intermediates 19-21 then followed by elimination of water molecule to afford the corresponding pyrazolo[1,5-a]pyrimidines derivatives 13a-h. 


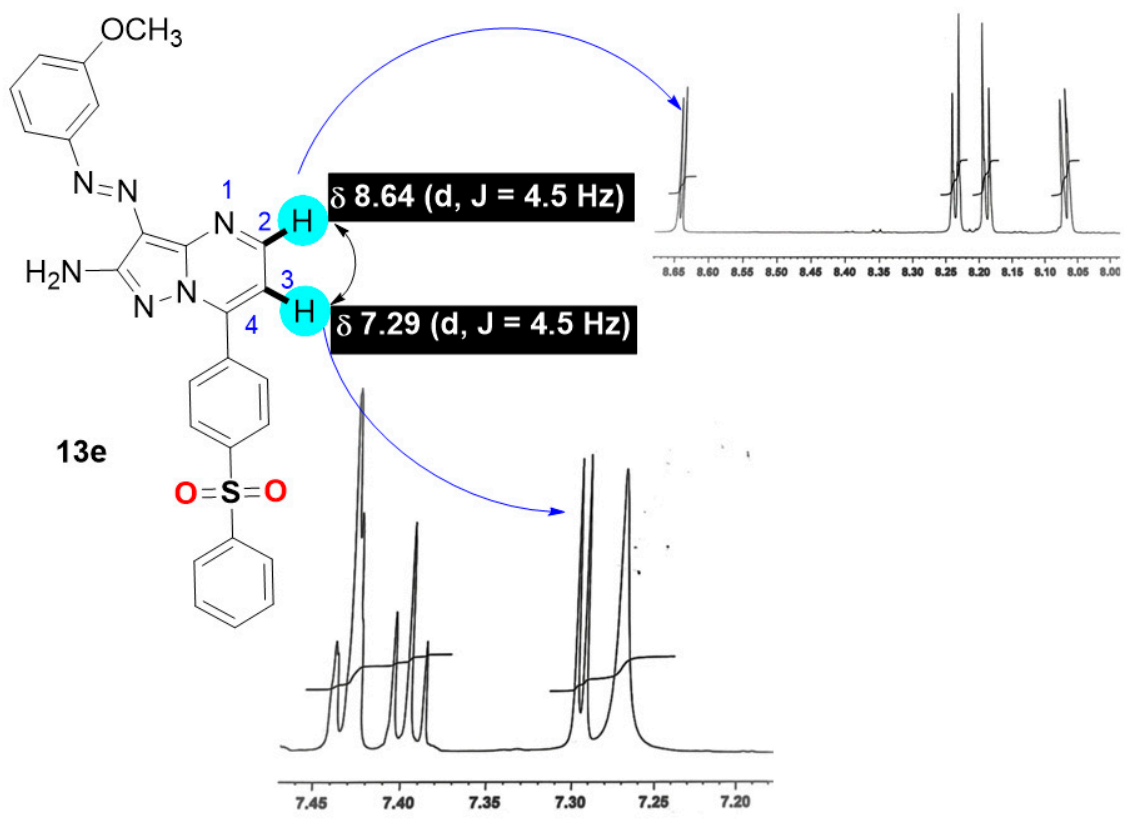

Figure $4 .{ }^{1} \mathrm{H}$ NMR of compound $13 \mathrm{e}$.

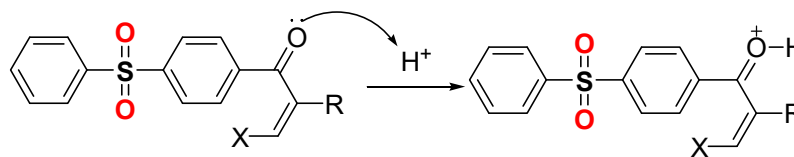

11, $\mathrm{X}=\mathrm{OEt}, \mathrm{R}=\mathrm{SO}_{2} \mathrm{Ph}$

12, $\mathrm{X}=\mathrm{NMe}_{2} \mathrm{R}=\mathrm{H}$
15

12<smiles>[R]Cc1ccc(S(=O)(=O)c2ccc(C(O)=C([R])C([Y])CC)cc2)cc1</smiles><smiles>[R]/C(=C/Nc1n[nH]c(N)c1N=N[Al])C(=O)c1ccc(S(=O)(=O)c2ccccc2)cc1</smiles>

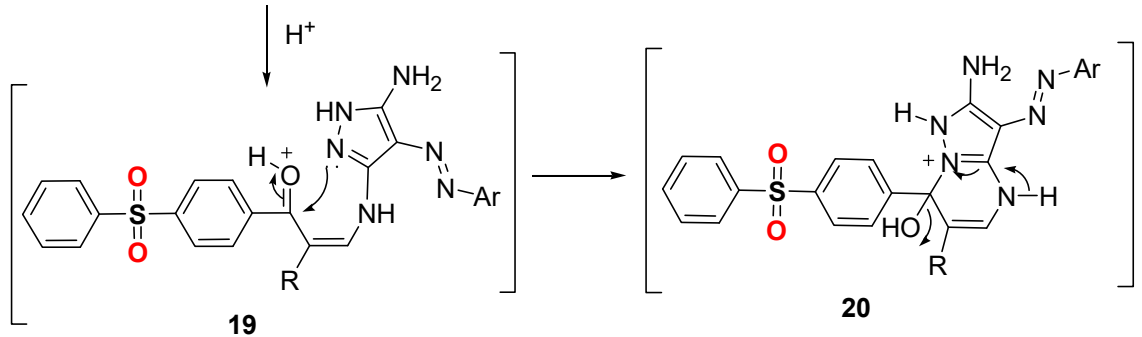

19

20

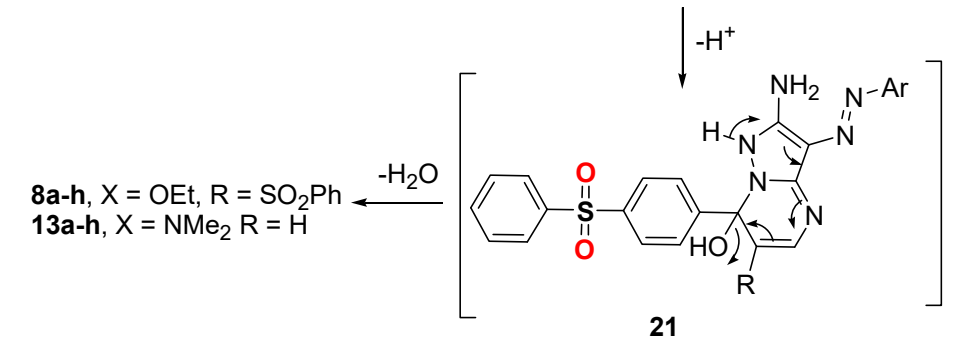

Scheme 6. The general mechanism of formation of compounds $\mathbf{8 a}-\mathbf{h}$ and $\mathbf{1 3 a} \mathbf{a} \mathbf{h}$ from ethoxymethylene derivative $\mathbf{1 1}$ and enaminone $\mathbf{1 2 .}$ 


\section{Antimicrobial Activity}

The antimicrobial activity of twelve new synthesized derivatives $8 \mathrm{a}-\mathbf{d}, \mathbf{8 h}, \mathbf{1 3} \mathbf{a}$, and $\mathbf{1 3} \mathbf{c}-\mathbf{h}$ were tested against two fungi species (Aspergillus niger and Geotrichum candidum) (Table 3), four Gram-positive bacteria as well as four Gram-negative which listed in Tables 4 and 5 . The reference drugs were commonly applied antibiotics such as Amphotericin B (For Fungi), Ampicillin, and Gentamicin (For Gram-positive and Gram-negative bacteria). The first thing that can be seen from the listed results of antimicrobial activity is that all the studied derivatives did not have any effect on P. aeruginosa and S. pyogenes. For the activity of the tested derivatives against two fungi: There are three pyrazolopyrimidine sulfone derivatives 13c, 13d, and 13g were found more potent than Amphotericin B.

Table 3. The antifungal activity of the tested derivatives $8 \mathbf{a}-\mathbf{d}, \mathbf{8 h}, \mathbf{1 3 a}$, and $\mathbf{1 3 c}-\mathbf{h}$.

\begin{tabular}{ccc}
\hline Compound No. & Aspergillus Niger * & Geotrichum Candidum ${ }^{*}$ \\
\hline $\mathbf{8 a}$ & $15.5 \pm 1.2$ & $17.4 \pm 0.72$ \\
$\mathbf{8 b}$ & $15.2 \pm 0.60$ & $17.2 \pm 0.63$ \\
$\mathbf{8 c}$ & $17.6 \pm 1.2$ & $18.5 \pm 0.63$ \\
$\mathbf{8 d}$ & $18.3 \pm 0.63$ & $19.3 \pm 0.58$ \\
$\mathbf{8 h}$ & $22.4 \pm 2.1$ & $24.3 \pm 2.1$ \\
$\mathbf{1 3 a}$ & $23.1 \pm 0.72$ & $22.6 \pm 0.72$ \\
$\mathbf{1 3 c}$ & $25.1 \pm 1.2$ & $22.6 \pm 1.2$ \\
$\mathbf{1 3 d}$ & $21.4 \pm 1.2$ & $25.2 \pm 1.2$ \\
$\mathbf{1 3 e}$ & $22.3 \pm 1.2$ & $20.4 \pm 0.58$ \\
$\mathbf{1 3 f}$ & $22.6 \pm 0.72$ & $23.6 \pm 1.20$ \\
$\mathbf{1 3 g}$ & $26.3 \pm 0.63$ & $23.2 \pm 0.63$ \\
$\mathbf{1 3 h}$ & $19.2 \pm 0.72$ & $17.3 \pm 0.72$ \\
Amphotericin $\mathbf{B}$ & $23.3 \pm 0.58$ & $25.2 \pm 0.72$ \\
\hline \multicolumn{2}{c}{ * The zone of inhibition (IZD) is measured in millimeter. }
\end{tabular}

Table 4. The antimicrobial activity of the tested derivatives $(\mu \mathrm{g} / \mathrm{mL})$ against Gram-positive bacteria.

\begin{tabular}{ccccc}
\hline Compound No. & S. aureus & S. epidermidis & B. subtilis & S. pyogenes \\
\hline $\mathbf{8 a}$ & $16.3 \pm 0.63$ & $15.8 \pm 0.58$ & $16.9 \pm 0.53$ & NA \\
$\mathbf{8 b}$ & $18.4 \pm 0.85$ & $15.7 \pm 1.2$ & $18.6 \pm 0.63$ & NA \\
$\mathbf{8 c}$ & $17.6 \pm 0.63$ & $16.4 \pm 0.72$ & $21.3 \pm 0.53$ & NA \\
$\mathbf{8 d}$ & $19.7 \pm 0.58$ & $18.3 \pm 0.58$ & $20.7 \pm 1.2$ & NA \\
$\mathbf{8 h}$ & $21.1 \pm 1.2$ & $20.8 \pm 0.67$ & $24.3 \pm 0.58$ & NA \\
$\mathbf{1 3 a}$ & $20.8 \pm 0.43$ & $20.6 \pm 0.58$ & $25.4 \pm 0.53$ & NA \\
$\mathbf{1 3 c}$ & $23.4 \pm 0.63$ & $21.8 \pm 0.72$ & $23.6 \pm 0.63$ & NA \\
$\mathbf{1 3 d}$ & $22.7 \pm 0.63$ & $22.6 \pm 0.72$ & $25.5 \pm 0.63$ & NA \\
$\mathbf{1 3 e}$ & $19.8 \pm 0.63$ & $16.7 \pm 0.58$ & $23.6 \pm 0.53$ & NA \\
$\mathbf{1 3 f}$ & $21.4 \pm 0.58$ & $17.7 \pm 0.72$ & $26.5 \pm 0.58$ & NA \\
$\mathbf{1 3 g}$ & $22.7 \pm 1.2$ & $22.3 \pm 0.58$ & $23.7 \pm 0.72$ & NA \\
13h & $13.5 \pm 1.2$ & $15.3 \pm 0.44$ & $18.2 \pm 0.58$ & NA \\
Ampicillin & $23.7 \pm 0.63$ & $22.4 \pm 1.2$ & $32.4 \pm 0.72$ & $24.5 \pm 0.63$ \\
\hline \multicolumn{5}{c}{ * The zone of inhibition (IZD) is measured in millimeter. }
\end{tabular}

In case of the activity against the Gram-positive bacteria only one derivative $13 \mathbf{d}$ exceeds the activity of the reference drug Ampicillin against S. epidermidis (Table 4). While, two derivatives $\mathbf{1 3} \mathbf{d}$ and $\mathbf{1 3} \mathbf{g}$ revealed activity more than the reference drug used against $E$. coli. Otherwise, three pyrazolopyrimidine derivatives 13c, $\mathbf{1 3 d}$, and $\mathbf{1 3} \mathbf{g}$ were found more reactive than Gentamicin against S. typhimurium (Table 5).

All the other tested pyrazolopyrimidines revealed activity good to moderate against all tested microbes except $P$. aeruginosa and S. pyogenes.

Minimum inhibitor concentration of the three most potent pyrazolopyrimidine derivatives $\mathbf{1 3 c}$, 13d, and 13g listed in Table 6 indicated that derivative 13d is the most effective compound. 
Table 5. The antimicrobial activity of the tested derivatives $(\mu \mathrm{g} / \mathrm{mL})$ against Gram-negative bacteria.

\begin{tabular}{|c|c|c|c|c|}
\hline Compound No. & P. aeruginosa & E. coli & K. pneumoniae & S. typhimurium \\
\hline $8 a$ & NA & $15.6 \pm 1.2$ & $11.8 \pm 0.44$ & $18.5 \pm 0.72$ \\
\hline $8 b$ & NA & $17.5 \pm 0.58$ & $14.8 \pm 1.2$ & $16.7 \pm 0.63$ \\
\hline $8 c$ & NA & $18.7 \pm 1.2$ & $15.9 \pm 1.2$ & $17.4 \pm 0.58$ \\
\hline $8 d$ & NA & $18.6 \pm 0.63$ & $17.6 \pm 0.58$ & $20.2 \pm 0.72$ \\
\hline $8 \mathrm{~h}$ & NA & $23.2 \pm 0.58$ & $21.3 \pm 0.58$ & $19.8 \pm 1.2$ \\
\hline $13 a$ & NA & $22.4 \pm 0.53$ & $20.4 \pm 0.53$ & $21.6 \pm 0.63$ \\
\hline $13 c$ & NA & $24.3 \pm 1.2$ & $22.5 \pm 1.2$ & $26.3 \pm 0.58$ \\
\hline $13 d$ & NA & $25.7 \pm 1.2$ & $26.6 \pm 1.2$ & $26.2 \pm 0.58$ \\
\hline $13 e$ & NA & $19.8 \pm 1.2$ & $18.4 \pm 0.53$ & $21.1 \pm 0.63$ \\
\hline $13 f$ & NA & $23.2 \pm 0.72$ & $19.5 \pm 0.63$ & $22.5 \pm 0.63$ \\
\hline $13 \mathrm{~g}$ & NA & $25.5 \pm 1.2$ & $23.3 \pm 1.2$ & $26.6 \pm 0.72$ \\
\hline $13 \mathrm{~h}$ & NA & $19.3 \pm 0.63$ & $16.3 \pm 0.63$ & $19.3 \pm 0.58$ \\
\hline Gentamicin & $22.3 \pm 0.58$ & $25.4 \pm 1.2$ & $2.6 \pm 0.63$ & $23.3 \pm 0.58$ \\
\hline
\end{tabular}

* The zone of inhibition (IZD) is measured in millimeter.

Table 6. Minimum inhibitory concentration $(\mu \mathrm{g} / \mathrm{mL})$ for compounds $\mathbf{1 5 c}, \mathbf{1 5 d}$, and $\mathbf{1 5 g}$.

\begin{tabular}{ccccc}
\hline Compound No. & $\mathbf{1 3 c}$ & $\mathbf{1 3 d}$ & $\mathbf{1 3 g}$ & Reference \\
\hline Fungi & & & & Amphotericin B \\
\hline $\begin{array}{c}\text { Aspergillus niger } \\
\text { Geotrichum candidum }\end{array}$ & 3.9 & 0.98 & 1.95 & 0.98 \\
\hline $\boldsymbol{G}^{+}$Bacteria & & 1.95 & 3.9 & 0.49 \\
\hline St. aureus & 3.9 & 3.9 & 15.63 & 0.98 \\
St. epidermidis & 15.63 & 7.81 & 31.25 & 1.95 \\
B. subtilis & 0.98 & 0.49 & 1.95 & 0.49 \\
St. pyogenes & $\mathrm{NA}$ & $\mathrm{NA}$ & $\mathrm{NA}$ & 0.49 \\
\hline $\boldsymbol{G}^{-}$Bacteria & & & & Gentamicin \\
\hline P. aeruginosa & $\mathrm{NA}$ & $\mathrm{NA}$ & $\mathrm{NA}$ & 1.95 \\
E. coli & 3.9 & 0.49 & 3.9 & 0.49 \\
K. pneumoniae & 7.81 & 3.9 & 15.63 & 0.98 \\
S. typhimurium & 3.9 & 1.95 & 3.9 & 0.98 \\
\hline
\end{tabular}

It is clear that the presence of one sulfone group in the pyrazolopyrimidine system enhances the antimicrobial activity of the synthesized drugs, and increasing the number of sulfone groups in our case does not increase the biological activity of the compounds. Therefore, we recommend the preparation of pyrazolopyrimidine system with one sulfone group and complete the study by determining the antibacterial activity of most promising compounds on mice models 3. Materials and Methods

\subsection{General}

Melting points of synthesized compounds were measured on a Gallenkamp melting point apparatus. The infrared spectra were recorded in potassium bromide discs Shimadzu a FT-IR-4100 infrared spectrophotometer (400-4000 cm-1, JASCO, Easton, MD, USA). Nuclear magnetic resonance spectra were recorded in DMSO- $d_{6}$ or $\mathrm{CDCl}_{3}$ Using a Varian Mercury VXR-300 NMR spectrometer (JEOL, Tokyo, Japan). Chemical shifts $\delta$ were related to that of the used solvents. MS spectra were recorded on a Shimadzu GCMS-QP1000 EX mass spectrometer at $70 \mathrm{eV}$ (Tokyo, Japan). The Microwave irradiation was carried out on a CEM mars machine (CEM Corporation, Matthews, NC, USA). CEM has several vessel types that are designed for their ovens: Closed-system vessels including the HP-500 (CEM Corporation, Matthews, NC, USA) (500 psig material design pressure and $260^{\circ} \mathrm{C}$ ), liners are composed of PFA, and are ideal for many types of samples. HP-500 Plus vessels are ideal for routine digestion applications. Process up to 14 high-pressure vessels per run with temperatures up to $260^{\circ} \mathrm{C}$ 
or pressures up to 500 psi. Elemental analyses were carried out at the microanalytical center of Cairo University, Giza, Egypt.

\subsection{Synthesis of 1-(4-benzenesulfonyl-phenyl)-2-bromo-ethanone (3)}

\subsubsection{Method A: Thermal Method}

To a stirred solution of 1-(4-benzenesulfonyl-phenyl)-ethanone (1) $(2.6 \mathrm{~g}, 0.01 \mathrm{~mol})$ and $p$-toluenesulfonic acid (2) (2 g, $0.01 \mathrm{~mol})$ in acetonitrile $(12 \mathrm{~mL})$ was added $\mathrm{N}$-bromosuccinimide $(1.78 \mathrm{~g}, 0.01 \mathrm{~mol})$ portion wise then the reaction mixture was heated for $3 \mathrm{~h}$. After the reaction mixture was cooled, the solvent was evaporated and $\mathrm{H}_{2} \mathrm{O}$ was added and the product was extracted using chloroform to give 1-(4-benzenesulfonyl-phenyl)-2-bromo-ethanone (3) as pale yellow solid, yield $(80 \%)$.

\subsubsection{Method B: Microwaves Method}

In a HP-500 process vial a mixture of 1-(4-benzenesulfonyl-phenyl)-ethanone (1) $(2.6 \mathrm{~g}, 0.01 \mathrm{~mol})$ and $p$-toluenesulfonic acid $(2 \mathrm{~g}, 0.01 \mathrm{~mol})$ in acetonitile $(12 \mathrm{~mL})$ was added $N$-bromosuccinimide $(1.78 \mathrm{~g}$, $0.01 \mathrm{~mol}$ ) portion wise then the vial was capped properly and was irradiated by microwaves irradiation ( $400 \mathrm{~W}$ power) using pressurized conditions at $90^{\circ} \mathrm{C}$ for a period of $15 \mathrm{~min}$. After the reaction mixture was cooled, the solvent was evaporated and $\mathrm{H}_{2} \mathrm{O}$ was added and the product was extracted using chloroform to give 1-(4-benzenesulfonyl-phenyl)-2-bromo-ethanone (3) as pale yellow solid, yield (94\%), mp.: $115-117^{\circ} \mathrm{C}(\mathrm{EtOH}), \mathrm{IR} v$ : 3091, $3011\left(\mathrm{sp}^{2} \mathrm{C}-\mathrm{H}\right), 2951\left(\mathrm{sp}^{3} \mathrm{C}-\mathrm{H}\right), 1705(\mathrm{C}=\mathrm{O}) \mathrm{cm}^{-1} ;{ }^{1} \mathrm{H}$ NMR (DMSO-d 6 ) $\delta 4.99\left(\mathrm{~s}, 2 \mathrm{H}, \mathrm{CH}_{2}\right), 7.64(\mathrm{t}, J=7.65 \mathrm{~Hz}, 2 \mathrm{H}, \mathrm{Ar}-\mathrm{H}), 7.72(\mathrm{t}, J=6.8 \mathrm{~Hz}, 1 \mathrm{H}, \mathrm{Ar}-\mathrm{H}), 8.01$ $(\mathrm{d}, J=7.65 \mathrm{~Hz}, 2 \mathrm{H}, \mathrm{Ar}-\mathrm{H}), 8.13(\mathrm{~d}, J=8.5 \mathrm{~Hz}, 2 \mathrm{H}, \mathrm{Ar}-\mathrm{H}), 8.18(\mathrm{~d}, J=7.65 \mathrm{~Hz}, 2 \mathrm{H}, \mathrm{Ar}-\mathrm{H}) .{ }^{13} \mathrm{C}$ NMR (DMSO-d 6 ) $\delta$ : $34.5\left(\mathrm{CH}_{2}\right), 127.7,127.9,129.9,130.0,134.2,137.8,140.2,145.1(8 \mathrm{Ar}-\mathrm{C}), 191.0(\mathrm{C}=\mathrm{O})$. Ms $m / z(\%) 340\left(\mathrm{M}^{+}+1,12\right), 339\left(\mathrm{M}^{+}, 20\right), 299$ (73), 267 (68), 253 (37), 246 (48), 220 (65), 168 (32), 120 (15), 93 (100), 77 (42), and 64 (37). Anal. Calcd. For: $\mathrm{C}_{14} \mathrm{H}_{11} \mathrm{BrO}_{3} \mathrm{~S}$ (339.20) C, 49.57; H, 3.27. Found: C, 49.46; $\mathrm{H}, 3.19 \%$

\subsection{Synthesis of 2-benzenesulfonyl-1-(4-benzenesulfonyl-phenyl)-ethanone (4)}

\subsubsection{Method A: Thermal Method}

A mixture of compound $3(3.4 \mathrm{~g}, 0.01 \mathrm{~mol})$ and sodium benzene sulfinate $(1.64 \mathrm{~g}, 0.01 \mathrm{~mol})$ in ethanol $(12 \mathrm{~mL})$ in suitable round flask was refluxed for $5 \mathrm{~h}$ with constant stirring. After the reaction was completed which evidenced using TLC technique, the reaction mixture was poured into ice cold water, the white precipitate was filtered off, dried, and crystallized from ethanol $/ n$-hexane to give the disulfone derivative 4 as white crystals, yield (95\%),

\subsubsection{Method B: Microwaves Method}

A mixture of compound $3(3.4 \mathrm{~g}, 0.01 \mathrm{~mol})$ and sodium benzene sulfinate $(1.64 \mathrm{~g}, 0.01 \mathrm{~mol})$ in ethanol $(12 \mathrm{~mL})$ were mixed in a HP-500 process vial. The vail was capped properly and was irradiated by microwaves irradiation ( $800 \mathrm{~W}$ power) using pressurized conditions at $70^{\circ} \mathrm{C}$ for a period of $25 \mathrm{~min}$. The reaction mixture was the reaction mixture was poured into ice cold water, the white precipitate was filtered off, dried, and crystallized from ethanol $/ n$-hexane to give the disulfone derivative 4 as white crystals, yield (96\%), mp.: 180-182 ${ }^{\circ} \mathrm{C}(\mathrm{EtOH}), \mathrm{IR} v: 3100$ (sp $\left.{ }^{2} \mathrm{C}-\mathrm{H}\right), 2951,2911$ (sp $\left.{ }^{3} \mathrm{C}-\mathrm{H}\right), 1700$ (C=O) $\mathrm{cm}^{-1} ;{ }^{1} \mathrm{H}$ NMR (DMSO- $\left.d_{6}\right) \delta: 5.39\left(\mathrm{~s}, 2 \mathrm{H}, \mathrm{CH}_{2}\right)$, and 7.53-8.13(m, $\left.14 \mathrm{H}, \mathrm{Ar}-\mathrm{H}\right) .{ }^{13} \mathrm{C}$ NMR (DMSO- $d_{6}$ ) $\delta: 62.6\left(\mathrm{CH}_{2}\right), 127.6,127.7,128.1,129.2,130.0,130.2,134.1,134.3,139.1,139.2,140.2,145.3(12 \mathrm{Ar}-\mathrm{C})$, 188.6 (C=O). Ms m/z (\%) $400\left(\mathrm{M}^{+}, 48\right), 362$ (55), 330 (100), 324 (23), 287 (63), 243 (41), 219 (41), 183 (16), 140 (40), 118 (19), 106 (9), and 41 (68). Anal. Calcd. For: $\mathrm{C}_{20} \mathrm{H}_{16} \mathrm{O}_{5} \mathrm{~S}_{2}$ (400.47) C, 59.98; H, 4.03. Found: C, $59.84 ; \mathrm{H}, 3.98 \%$. 
3.4. Synthesis of 2-benzenesulfonyl-1-(4-benzenesulfonyl-phenyl)-3-dimethylamino-propenone (6) and 1-(4-benzenesulfonyl-phenyl)-3-dimethylamino-propenone (12)

\subsubsection{Method A: Thermal Method}

A mixture of 2-benzenesulfonyl-1-(4-benzenesulfonyl-phenyl)-ethanone (4) or 1-(4-(phenylsulfonyl)phenyl)ethan-1-one (1) $(0.005 \mathrm{~mol})$ and DMF-DMF $(0.7 \mathrm{~g}, 0.005 \mathrm{~mol})$ in xylene $(20 \mathrm{~mL})$ was heated under reflux for the sufficient time of reaction (checked by TLC). After the reaction was completed, the solvent was evaporated and the residue was triturated with hexane to give a solid product that was collected by filtration and crystallized from the proper solvent to give enaminodi-sulfone 6 or enaminosulfone 12, with isolated yields $83 \%$ and $94 \%$, respectively.

\subsubsection{Method B: Microwaves Method}

A mixture of 2-benzenesulfonyl-1-(4-benzenesulfonyl-phenyl)-ethanone (4) or 1-(4-(phenylsulfonyl)phenyl)ethan-1-one (1) (0.005 mol), DMF-DMF ( $0.7 \mathrm{~g}, 0.005 \mathrm{~mol})$, and xylene $(20 \mathrm{~mL})$ were mixed in a HP-500 process vial. The vail was capped properly and was irradiated by microwaves irradiation ( $400 \mathrm{~W}$ power) using pressurized conditions at $110{ }^{\circ} \mathrm{C}$ for a period of $30-40 \mathrm{~min}$. the excess xylene was evaporated and the residue was triturated with hexane to give a solid product that was collected by filtration and crystallized from ethanol to give enaminosulfone 6 or enaminone 12, with isolated yields $91 \%$ and $96 \%$, respectively.

The physical and spectral data of the synthesized compounds $\mathbf{6}$ and $\mathbf{1 2}$ are listed below.

2-benzenesulfonyl-1-(4-benzenesulfonyl-phenyl)-3-dimethylamino-propenone (6), $\mathrm{mp} .: 212-214{ }^{\circ} \mathrm{C}$, IR v́: $3059\left(\mathrm{sp}^{2} \mathrm{C}-\mathrm{H}\right), 2933\left(\mathrm{sp}^{3} \mathrm{CH}\right), 1624(\mathrm{C}=\mathrm{O}) \mathrm{cm}^{-1} ;{ }^{1} \mathrm{H}$ NMR (DMSO-d $) \delta: 3.29\left(\mathrm{~s}, 6 \mathrm{H}, 2 \mathrm{CH}_{3}\right)$, 7.36-7.99 (m, 14H, Ar-H), $8.11(\mathrm{~s}, 1 \mathrm{H},=\mathrm{CH}) .{ }^{13} \mathrm{C} \mathrm{NMR}\left(\mathrm{DMSO}-d_{6}\right) \delta: 34.3\left(\mathrm{CH}_{3}\right), 106.2,120.6,126.1$, 127.4, 127.9, 128.5, 129.7, 130.5, 133.5, 140.5, 143.4, 143.9, 144.3, 156.1, and 187.2 (C=O). Ms m/z (\%) 455 $\left(\mathrm{M}^{+}, 39\right), 440$ (13), 431 (100), 429 (100), 412 (25), 378 (31), 314 (13), 237 (24), 218 (35), 144 (82), 141 (26), 77 (34), and 43 (26). Anal. Calcd. For: $\mathrm{C}_{23} \mathrm{H}_{21} \mathrm{NO}_{5} \mathrm{~S}_{2}$ (455.55) C, 60.64; $\mathrm{H}, 4.65 ; \mathrm{N}, 3.07$. Found: $\mathrm{C}$, 60.54; $\mathrm{H}, 4.49 ; \mathrm{N}, 3.12 \%$.

1-(4-benzenesulfonyl-phenyl)-3-dimethylamino-propenone (12), $\mathrm{mp} .: \quad 225-227{ }^{\circ} \mathrm{C}$, IR $v$ : $3100\left(\mathrm{sp}^{2}-\mathrm{CH}\right), 2921\left(\mathrm{sp}^{3}-\mathrm{CH}\right), 1644(\mathrm{C}=\mathrm{O}) \mathrm{cm}^{-1} ;{ }^{1} \mathrm{H}$ NMR (DMSO-d $)$ ) $\delta: 2.91,3.15\left(2 \mathrm{~s}, 6 \mathrm{H}, 2 \mathrm{CH}_{3}\right)$, $5.77(\mathrm{~d}, J=12 \mathrm{~Hz}, 1 \mathrm{H},=\mathrm{CH}), 7.59-7.73$ and 7.89-8.11 $(\mathrm{m}, 9 \mathrm{H}, \mathrm{Ar}-\mathrm{H})$, and $7.74(\mathrm{~d}, J=12 \mathrm{~Hz}, 1 \mathrm{H},=\mathrm{CH})$. ${ }^{13} \mathrm{C}$ NMR (DMSO- $\left.d_{6}\right) \delta: 44.6\left(2 \mathrm{CH}_{3}\right), 91.0,127.3,128.2,129.7,133.8,140.8,142.4,144.7,154.9$, and 184.0 $(\mathrm{C}=\mathrm{O})$. Ms $m / z(\%) 315(\mathrm{M}+, 8), 302$ (71), 272 (14), 258 (6), 245 (16), 218 (9), 140 (7), 99 (15), 77 (24), 56 (100), and 44 (88). Anal. Calcd. For: $\mathrm{C}_{17} \mathrm{H}_{17} \mathrm{NO}_{3} \mathrm{~S}$ (315.39) C, 64.74; $\mathrm{H}, 5.43 ; \mathrm{N}, 4.44$. Found: $\mathrm{C}, 64.59$; $\mathrm{H}, 5.21 ; \mathrm{N}, 4.36 \%$.

\subsection{Synthesis of 2-benzenesulfonyl-1-(4-benzenesulfonyl-phenyl)-3-ethoxy-propenone (11)}

Fusion of disulfone derivative $4(0.4 \mathrm{~g}, 0.001 \mathrm{~mol})$ and triethylorthoformate $(1 \mathrm{~mL})$ in round flask was achieved on hotplate for $15 \mathrm{~min}$ to form clear solution. After the solution was left to cool, the solid formed was collected by filtration and crystallized from ethanol to give white crystals, yield $(80 \%)$, mp.: 165-167 ${ }^{\circ} \mathrm{C}$, IR v́: 3101 (sp $\left.{ }^{2}-\mathrm{CH}\right), 2911$ (sp $\left.{ }^{3}-\mathrm{CH}\right), 1700(\mathrm{C}=\mathrm{O}) \mathrm{cm}^{-1}$; Ms m/z (\%) $456\left(\mathrm{M}^{+}, 100\right)$, 274 (99), 103 (54), Anal. Calcd.For: $\mathrm{C}_{23} \mathrm{H}_{20} \mathrm{O}_{6} \mathrm{~S}_{2}$ (456.53) C, 60.51; H, 4.42. Found: C, 60.38; $\mathrm{H}, 4.25 \%$.

\subsection{Synthesis of pyrazolo[1,5-a]pyrimidine derivatives $8 \boldsymbol{a}-\boldsymbol{h}$ and $\mathbf{1 3 a} \boldsymbol{h}$}

\subsubsection{Thermal Methods}

Method A: Enaminodisulfone 6 or enaminosulfone $12(0.001 \mathrm{~mol})$ was reacted with the appropriate arylazodiaminopyrazoles $7 \mathbf{a}-\mathbf{h}(0.001 \mathrm{~mol})$ in $20 \mathrm{~mL}$ glacial acetic acid under reflux for $7 \mathrm{~h}$. The reaction mixture was left to cool and the precipitated solid product was collected by filtration, washed with EtOH, dried and finally recrystallized from $\mathrm{DMF} / \mathrm{EtOH}$ to afford the corresponding pyrazolo[1,5-a]pyrimidines 
$\mathbf{8} \mathbf{a}-\mathbf{h}$ or $\mathbf{1 3} \mathbf{a}-\mathbf{h}$. The physical and spectral data of the synthesized compounds $\mathbf{8} \mathbf{a}-\mathbf{h}$ and $\mathbf{1 3} \mathbf{a}-\mathbf{h}$ are listed below.

Method B (for compounds 8a-h only): A solution of disulfone derivative $4(0.4 \mathrm{~g}, 0.001 \mathrm{~mol})$ and an equivalent molar ratio of the appropriate arylazodiaminopyrazoles $\mathbf{7 a}-\mathbf{h}$ in triethylorthoformate $(20 \mathrm{~mL})$, was heated under reflux for $7 \mathrm{~h}$. The excess solvent was removed by distillation under reduced pressure and the residue was left to cool. The precipitated solid product was collected by filtration, washed with $\mathrm{EtOH}$, dried, and finally recrystallized from $\mathrm{DMF} / \mathrm{EtOH}$ to afford the corresponding pyrazolo[1,5-a]pyrimidines $8 \mathbf{a}-\mathbf{h}$.

Method C (for compounds 8a-h only): Compound 11 (0.001 mol) was reacted with the appropriate arylazodiaminopyrazoles $7 \mathbf{a}-\mathbf{h}(0.001 \mathrm{~mol})$ in $20 \mathrm{~mL}$ glacial acetic acid under reflux for $7 \mathrm{~h}$. The reaction mixture was left to cool and the precipitated solid product was collected by filtration, washed with $\mathrm{EtOH}$, dried, and finally recrystallized from $\mathrm{DMF} / \mathrm{EtOH}$ to afford the corresponding pyrazolo[1,5-a]pyrimidines $8 \mathbf{a}-\mathbf{h}$.

\subsubsection{Microwaves Methods}

Method A: A mixture of Enaminone 6 or enaminone $12(0.001 \mathrm{~mol})$ and the appropriate arylazodiaminopyrazoles $7 \mathbf{a}-\mathbf{h}(0.001 \mathrm{~mol})$ in in $20 \mathrm{~mL}$ glacial acetic acid were mixed in a HP-500 process vial. The vail was capped properly and was irradiated by microwaves irradiation ( $800 \mathrm{~W}$ power) using pressurized conditions at $110^{\circ} \mathrm{C}$ for $15 \mathrm{~min}$. The reaction mixture was left to cool and the precipitated solid product was collected by filtration, washed with $\mathrm{EtOH}$, dried, and finally recrystallized from $\mathrm{DMF} / \mathrm{EtOH}$ to afford the corresponding pyrazolo[1,5-a]pyrimidines $\mathbf{8} \mathbf{a}-\mathbf{h}$ or $\mathbf{1 3} \mathbf{a}-\mathbf{h}$. The physical and spectral data of the synthesized compounds $\mathbf{8} \mathbf{a}-\mathbf{h}$ and $\mathbf{1 3} \mathbf{a}-\mathbf{h}$ are listed below.

Method B (for compounds 8a-h only): A mixture of disulfone derivative $4(0.4 \mathrm{~g}, 0.001 \mathrm{~mol})$ and an equivalent molar ratio of the appropriate arylazodiaminopyrazoles $7 \mathbf{a}-\mathbf{h}$ in triethylorthoformate $(20 \mathrm{~mL})$, was mixed in a HP-500 process vial. The vail was capped properly and was irradiated by microwaves irradiation ( $800 \mathrm{~W}$ power) using pressurized conditions at $110^{\circ} \mathrm{C}$ for $15 \mathrm{~min}$. The reaction mixture was left to cool and the precipitated solid product was collected by filtration, washed with EtOH, dried, and finally recrystallized from $\mathrm{DMF} / \mathrm{EtOH}$ to afford the corresponding pyrazolo[1,5-a]pyrimidines $\mathbf{8} \mathbf{a}-\mathbf{h}$. The physical and spectral data of the synthesized compounds $\mathbf{8} \mathbf{a}-\mathbf{h}$ and $\mathbf{1 3} \mathbf{a}-\mathbf{h}$ are listed below.

Method C (for compounds 8a-h only): A mixture of compound $\mathbf{1 1}(0.001 \mathrm{~mol})$ and the appropriate arylazodiaminopyrazoles $7 \mathbf{a}-\mathbf{h}(0.001 \mathrm{~mol})$ in in $20 \mathrm{~mL}$ glacial acetic acid were mixed in a HP-500 process vial. The vail was capped properly and was irradiated by microwaves irradiation $(800 \mathrm{~W}$ power) using pressurized conditions at $110{ }^{\circ} \mathrm{C}$ for $15 \mathrm{~min}$. The reaction mixture was left to cool and the precipitated solid product was collected by filtration, washed with $\mathrm{EtOH}$, dried, and finally recrystallized from $\mathrm{DMF} / \mathrm{EtOH}$ to afford the corresponding pyrazolo[1,5-a]pyrimidines $\mathbf{8 a}-\mathbf{h}$.

\section{6-Benzenesulfonyl-7-(4-benzenesulfonyl-phenyl)-3-(4-chloro-phenylazo)- pyrazolo[1,5-a]pyrimidin-2-ylamine (8a)}

Yellow solid, mp.: $235-237{ }^{\circ} \mathrm{C}$, IR v: 3464, $3362\left(\mathrm{NH}_{2}\right), 3100\left(\mathrm{sp}^{2}-\mathrm{CH}\right), 2900\left(\mathrm{sp}^{3}-\mathrm{CH}\right)$, $1616(\mathrm{C}=\mathrm{N}) \mathrm{cm}^{-1} ;{ }^{1} \mathrm{H}$ NMR (DMSO- $\left.d_{6}\right) \delta: 7.17-7.89\left(\mathrm{~m}, 12 \mathrm{H}, \mathrm{Ar}-\mathrm{H}\right.$ and $\left.\mathrm{NH}_{2}\right), 7.56(\mathrm{~d}, J=8 \mathrm{~Hz}$, 2H, Ar-H), 7.86 (d, J = 8 Hz, 2H, Ar-H), $7.92(\mathrm{~d}, J=8 \mathrm{~Hz}, 2 \mathrm{H}, \mathrm{Ar}-\mathrm{H}), 8.09$ (d, J = 8 Hz, 2H, Ar-H), 9.17 (s, $1 \mathrm{H}$, pyrimidine-H). ${ }^{13} \mathrm{C}$ NMR (DMSO- $d_{6}$ ) $\delta: 115.6,120.6,122.1,123.0,126.7,127.0,127.7,128.9,129.1$, $129.9,130.9,132.3,133.6,134.1,140.1,140.5,142.8,144.9,147.9,148.7,151.4,153.9$. Ms $\mathrm{m} / \mathrm{z}(\%) 628$ $\left(\mathrm{M}^{+}, 16\right), 557$ (14), 521(28), 508 (93), 483 (15), 410 (38), 381 (98), 346 (16), 335 (100), 274 (17), 236 (27), 217 (13). Anal. Calcd. For: $\mathrm{C}_{30} \mathrm{H}_{21} \mathrm{ClN}_{6} \mathrm{O}_{4} \mathrm{~S}_{2}$ (629.11) C, 57.27; H, 3.36; N, 13.36. Found: C, 57.09; H, 3.16; $\mathrm{N}, 13.27 \%$.

\section{6-Benzenesulfonyl-7-(4-benzenesulfonyl-phenyl)-3-(3-methyl-phenylazo)- pyrazolo[1,5-a]pyrimidin-2-ylamine (8b)}


Pale brown solid, mp.: $233-235^{\circ} \mathrm{C}$, IR v́: 3459, $3337\left(\mathrm{NH}_{2}\right), 3096\left(\mathrm{sp}^{2}-\mathrm{CH}\right), 2980\left(\mathrm{sp}^{3}-\mathrm{CH}\right)$, $1609(\mathrm{C}=\mathrm{N}) \mathrm{cm}^{-1} ;{ }^{1} \mathrm{H}$ NMR (DMSO- $\left.d_{6}\right) \delta: 2.39\left(\mathrm{~s}, 3 \mathrm{H}, \mathrm{CH}_{3}\right), 7.15-7.80\left(\mathrm{~m}, 16 \mathrm{H}, \mathrm{Ar}-\mathrm{H}\right.$ and $\left.\mathrm{NH}_{2}\right), 7.99$ $(\mathrm{d}, J=9 \mathrm{~Hz}, 2 \mathrm{H}, \mathrm{Ar}-\mathrm{H}), 8.09(\mathrm{~d}, J=9 \mathrm{~Hz}, 2 \mathrm{H}, \mathrm{Ar}-\mathrm{H})$, and $9.16\left(\mathrm{~s}, 1 \mathrm{H}\right.$, pyrimidine-H) ${ }^{13} \mathrm{C}$ NMR (DMSO- $\left.d_{6}\right)$ $\delta$ : $20.9\left(\mathrm{CH}_{3}\right), 115.4,119.2,121.5,121.8,126.8,127.0,127.8,128.9,129.1,130.0,130.2,131.0,132.4,133.7$, $134.2,138.5,140.2,140.6,142.7,144.9,147.8,148.5,152.7$, and 154.0. Ms $m / z(\%) 610\left(\mathrm{M}^{+}+2,13\right), 608$ $\left(\mathrm{M}^{+}, 23\right), 593$ (14), 541 (100), 532 (23), 517 (32), 489 (16), 391 (34), 326 (9), 235 (16), 217 (9), 140 (15), 129 (90), 95 (43), and 76 (10). Anal. Calcd. For: $\mathrm{C}_{31} \mathrm{H}_{24} \mathrm{~N}_{6} \mathrm{O}_{4} \mathrm{~S}_{2}$ (608.69) C, 61.17; H, 3.97; N, 13.81. Found: C, 61.03; H, 3.82; N, 13.69\%.

\section{6-Benzenesulfonyl-7-(4-benzenesulfonyl-phenyl)-3-(3-chloro-phenylazo)-} pyrazolo[1,5-a]pyrimidin-2-ylamine (8c)

Yellow crystals, mp.: $260-262{ }^{\circ} \mathrm{C}$, IR v́: 3408, $3280\left(\mathrm{NH}_{2}\right), 3068\left(\mathrm{sp}^{2}-\mathrm{CH}\right) 1616(\mathrm{C}=\mathrm{N}) ;{ }^{1} \mathrm{H}$ NMR (DMSO- $\left.d_{6}\right) \delta: 3.57\left(\mathrm{~s}, 2 \mathrm{H}, \mathrm{NH}_{2}\right), 7.16(\mathrm{t}, J=7.65 \mathrm{~Hz}, 2 \mathrm{H}, \mathrm{Ar}-\mathrm{H}), 7.30(\mathrm{~d}, J=8.5 \mathrm{~Hz}, 2 \mathrm{H}, \mathrm{Ar}-\mathrm{H}), 7.46$ (d, J = 7.65 Hz, 2H, Ar-H), 7.53-7.86 (m, 7H, Ar-H), 7.95 (s, 1H, Ar-H), 7.99 (d, J = 7.65 Hz, 2H, Ar-H), $8.10\left(\mathrm{~d}, J=7.65 \mathrm{~Hz}, 2 \mathrm{H}, \mathrm{Ar}-\mathrm{H}\right.$ ), and $9.19(\mathrm{~s}, 1 \mathrm{H}, \mathrm{N}=\mathrm{CH}) .{ }^{13} \mathrm{C}$ NMR (DMSO- $\left.d_{6}\right) \delta: 115.8,120.4,120.9$, 122.4, 126.9, 127.1, 127.9, 128.8, 129.0, 130.0, 130.1, 131.0, 132.4, 133.8, 134.0, 134.3, 140.1, 140.6, 142.8, 145.1, 148.1, 148.8, 153.9, and 154.0. Ms $m / z(\%) 628\left(\mathrm{M}^{+}-1,18\right), 552$ (27), 520 (11), 483 (17), 409 (26), 345 (15), 274 (10), 236 (15), 216 (17), 111 (8), and 72 (100). Anal. Calcd. For: $\mathrm{C}_{30} \mathrm{H}_{21} \mathrm{ClN}_{6} \mathrm{O}_{4} \mathrm{~S}_{2}$ (629.11) C, 57.27; H, 3.36; N, 13.36. Found: C, 57.08; H, 3.21 N, 13.29\%.

\section{6-Benzenesulfonyl-7-(4-benzenesulfonyl-phenyl)-3-(2-chloro-phenylazo)- pyrazolo[1,5-a]pyrimidin-2-ylamine (8d)}

Yellow solid, mp.: $250-252{ }^{\circ} \mathrm{C}$, IR v́:br. $3458\left(\mathrm{NH}_{2}\right), 1612(\mathrm{C}=\mathrm{N}) ;{ }^{1} \mathrm{H}$ NMR (DMSO-d $\left.d_{6}\right) 5.40$ $\left(\mathrm{s}, 2 \mathrm{H}, \mathrm{NH}_{2}\right), 7.17-7.82(\mathrm{~m}, 14 \mathrm{H}, \mathrm{Ar}-\mathrm{H}), 7.98(\mathrm{~d}, J=8 \mathrm{~Hz}, 2 \mathrm{H}, \mathrm{Ar}-\mathrm{H}), 8.09(\mathrm{~d}, J=8 \mathrm{~Hz}, 2 \mathrm{H}, \mathrm{Ar}-\mathrm{H})$, and $9.22\left(\mathrm{~s}, 1 \mathrm{H}\right.$, pyrimidine-H). ${ }^{13} \mathrm{C}$ NMR (DMSO- $d_{6}$ ) $\delta: 111.9,116.4,116.7,122.7,126.8,127.8,127.1,127.6$, 128.1, 128.9, 130.3, 130.7, 132.2, 132.3, 134.2, 138.0, 139.9, 140.5, 142.8, 145.2, 147.8, 149.0, 153.7, and 156.7. Ms m/z (\%) 629 (M+ , 32), 579 (100), 552 (49), 519 (17), 504 (35), 489 (15), 412 (7), 346 (34), 275 (8), 141 (6), and 111 (19). Anal. Calcd. For: $\mathrm{C}_{30} \mathrm{H}_{21} \mathrm{ClN}_{6} \mathrm{O}_{4} \mathrm{~S}_{2}$ (629.11) C, 57.27; H, 3.36; N, 13.36. Found: C, 57.07; $\mathrm{H}, 3.30 ; \mathrm{N}, 13.15 \%$.

\section{6-Benzenesulfonyl-7-(4-benzenesulfonyl-phenyl)-3-(3-methoxy-phenylazo)- pyrazolo[1,5-a]pyrimidin-2-ylamine (8e)}

Dark yellow solid, mp.: 200-202 ${ }^{\circ} \mathrm{C}$, IR $v$ br. $3450\left(\mathrm{NH}_{2}\right), 1618(\mathrm{C}=\mathrm{N}) ;{ }^{1} \mathrm{H}$ NMR (DMSO-d 6 ) $\delta: 3.57$ $\left(\mathrm{s}, 3 \mathrm{H}, \mathrm{OCH}_{3}\right), 5.40\left(\mathrm{~s}, 2 \mathrm{H}, \mathrm{NH}_{2}\right), 7.56-8.12(\mathrm{~m}, 18 \mathrm{H}, \mathrm{Ar}-\mathrm{H})$, and $9.17(\mathrm{~s}, 1 \mathrm{H}$, pyrimidine-H). Ms $\mathrm{m} / \mathrm{z}(\%)$ $624\left(\mathrm{M}^{+}, 50\right), 453$ (87), 439 (99), 318 (94), and 274 (100). Anal. Calcd.For: $\mathrm{C}_{31} \mathrm{H}_{24} \mathrm{~N}_{6} \mathrm{O}_{5} \mathrm{~S}_{2}$ (624.69) $\mathrm{C}$, 59.60; H, 3.87; N, 13.45. Found: C, 59.46; H, 3.73; N, 13.21\%.

\section{6-Benzenesulfonyl-7-(4-benzenesulfonyl-phenyl)-3-phenylazo-pyrazolo[1,5-a]pyrimidin-2-ylamine (8f)}

Dark yellow solid, mp.: $270-272{ }^{\circ} \mathrm{C}$, IR $v$ : br, $3456\left(\mathrm{NH}_{2}\right), 1614(\mathrm{C}=\mathrm{N}) ;{ }^{1} \mathrm{H}$ NMR (DMSO- $\left.d_{6}\right) \delta$ : 7.15-7.89 (m, 15H, Ar-H), $7.98(\mathrm{~d}, J=8 \mathrm{~Hz}, 2 \mathrm{H}, \mathrm{Ar}-\mathrm{H}), 8.09(\mathrm{~d}, J=8 \mathrm{~Hz}, 2 \mathrm{H}, \mathrm{Ar}-\mathrm{H})$, and $9.18(\mathrm{~s}, 1 \mathrm{H}$, pyrimidine-H). ${ }^{13} \mathrm{C}$ NMR (DMSO- $d_{6}$ ) $\delta: 115.4,121.6,121.9,126.9,127.1,127.9,129.0,129.2,129.6,130.1$, 131.0, 132.5, 133.8, 134.3, 140.2, 140.6, 142.8, 145.0, 147.9, 148.6, 152.7, and 154.0. Ms $\mathrm{m} / z(\%) 594\left(\mathrm{M}^{+}, 20\right)$, 580 (18), 523 (22), 490 (32), 457 (49), 375 (100), 273 (28), 218 (28), 142 (24), and 77 (27). Anal. Calcd. For: $\mathrm{C}_{30} \mathrm{H}_{22} \mathrm{~N}_{6} \mathrm{O}_{4} \mathrm{~S}_{2}$ (594.66) C, 60.59; H, 3.73; N, 14.13. Found: $\mathrm{C}, 60.46 ; \mathrm{H}, 3.61 ; \mathrm{N}, 14.02 \%$.

\section{6-Benzenesulfonyl-7-(4-benzenesulfonyl-phenyl)-3-(2-nitro-phenylazo)- pyrazolo[1,5-a]pyrimidin-2-ylamine $(8 \mathrm{~g})$}

Dark red solid, mp.: $285-287^{\circ} \mathrm{C}$, IR $v: 3446,3340\left(\mathrm{NH}_{2}\right), 1620,1585(\mathrm{C}=\mathrm{N}) . ;^{1} \mathrm{H}$ NMR $\left(\mathrm{DMSO}-d_{6}\right) \delta$ : 7.16-8.12 (m, 20H, Ar-H), 9.23 (s, 1H, pyrimidine-H). ${ }^{13} \mathrm{C}$ NMR (DMSO-d 6 ) $\delta: 117.3,117.4,120.5,123.3$, 124.4, 126.8, 127.1, 127.8, 128.9, 129.5, 129.9, 130.9, 132.2, 133.6, 133.8, 134.2, 139.9, 140.6, 142.9, 144.6, 145.3, 146.0, 149.4, and 153.6. Ms $m / z(\%) 639\left(\mathrm{M}^{+}, 23\right), 620$ (19), 563 (15), 516 (13), 494 (14), 438 (99), 
423 (32), 148 (21), 137 (17), 123 (12), 77 (8), and 60 (100). Anal. Calcd. For: $\mathrm{C}_{30} \mathrm{H}_{21} \mathrm{~N}_{7} \mathrm{O}_{6} \mathrm{~S}_{2}$ (639.66) C, 56.33; H, 3.31; N, 15.33. Found: C, 56.18; H, 3.29; N, $15.08 \%$.

\section{6-Benzenesulfonyl-7-(4-benzenesulfonyl-phenyl)-3-(4-methoxy-phenylazo)- pyrazolo[1,5-a]pyrimidin-2-ylamine (8h)}

Pale brown solid, mp.: $220-222^{\circ} \mathrm{C}(\mathrm{EtOH})$, IR v́: br. $3450\left(\mathrm{NH}_{2}\right), 1616(\mathrm{C}=\mathrm{N}) ;{ }^{1} \mathrm{H}$ NMR (DMSO- $\left.d_{6}\right)$ $\delta: 3.83\left(\mathrm{~s}, 3 \mathrm{H}, \mathrm{OCH}_{3}\right), 7.05(\mathrm{~d}, J=8 \mathrm{~Hz}, 2 \mathrm{H}, \mathrm{Ar}-\mathrm{H}), 7.14-7.47(\mathrm{~m}, 10 \mathrm{H}, \mathrm{Ar}-\mathrm{H}), 7.53\left(\mathrm{~s}, 2 \mathrm{H}, \mathrm{NH}_{2}\right), 7.85$ $(\mathrm{d}, J=8 \mathrm{~Hz}, 2 \mathrm{H}, \mathrm{Ar}-\mathrm{H}), 7.97(\mathrm{~d}, J=8 \mathrm{~Hz}, 2 \mathrm{H}, \mathrm{Ar}-\mathrm{H}), 8.09(\mathrm{~d}, J=8 \mathrm{~Hz}, 2 \mathrm{H}, \mathrm{Ar}-\mathrm{H})$, and $9.13(\mathrm{~s}, 1 \mathrm{H}$, pyrimidine-H). ${ }^{13} \mathrm{C}$ NMR (DMSO- $d_{6}$ ) $\delta: 55.5,114.4,115.0,121.4,123.1,126.8,127.0,127.8,128.9,129.9$, $130.9,132.5,133.6,134.1,140.3,140.6,142.8,144.8,146.8,147.2,148.2,154.2$, and 160.6. Ms $\mathrm{m} / \mathrm{z}(\%) 624$ $\left(\mathrm{M}^{+}, 24\right), 550$ (16), $488(18), 407$ (47), 273 (38), 217 (44), 159 (100), 133 (6), and 80 (28). Anal. Calcd. For: $\mathrm{C}_{31} \mathrm{H}_{24} \mathrm{~N}_{6} \mathrm{O}_{5} \mathrm{~S}_{2}(624.69) \mathrm{C}, 59.60 ; \mathrm{H}, 3.87 ; \mathrm{N}, 13.45$. Found: $\mathrm{C}, 59.42 ; \mathrm{H}, 3.70 ; \mathrm{N}, 13.31 \%$.

\section{7-(4-Benzenesulfonyl-phenyl)-3-(4-chloro-phenylazo)- pyrazolo[1,5-a]pyrimidin-2-ylamine (13a)}

Orange crystals, mp.: $280-282{ }^{\circ} \mathrm{C}(\mathrm{EtOH}), \mathrm{IR} v$ v: 3421, $3298\left(\mathrm{NH}_{2}\right), 3099\left(\mathrm{sp}^{2}-\mathrm{CH}\right), 2900\left(\mathrm{sp}^{3}-\mathrm{CH}\right)$, $1616(\mathrm{C}=\mathrm{N}) \mathrm{cm}^{-1} ;{ }^{1} \mathrm{H}$ NMR (DMSO- $\left.d_{6}\right) \delta: 7.30(\mathrm{~d}, J=3.9 \mathrm{~Hz}, 1 \mathrm{H}$, Pyrimidine-H), $7.52(\mathrm{~d}, J=9 \mathrm{~Hz}$, 2H, Ar-H), 7.68-7.70 (m, 7H, Ar-H and $\left.\mathrm{NH}_{2}\right), 7.83(\mathrm{~d}, \mathrm{~J}=9 \mathrm{~Hz}, 2 \mathrm{H}, \mathrm{Ar}-\mathrm{H}), 8.04-8.25(\mathrm{~m}, 4 \mathrm{H}, \mathrm{Ar}-\mathrm{H})$, $8.63\left(\mathrm{~d}, J=3.9 \mathrm{~Hz}\right.$, and $1 \mathrm{H}$, Pyrimidine-H). ${ }^{13} \mathrm{C}$ NMR (DMSO- $\left.d_{6}\right) \delta: 110.0,114.9,122.8,127.4,127.7$, 129.18, 130.0, 131.0, 132.7, 134.2, 135.2, 140.6, 142.9, 143.5, 147.6, 150.9, 151.7, and 151.9. Ms m/z (\%) 488 $\left(\mathrm{M}^{+}, 14\right), 414$ (14), 363 (24), 270 (17), 255 (29), 218 (13), 140 (9), 131 (100), 121 (74), 110 (24), and 102 (29). Anal. Calcd. For: $\mathrm{C}_{24} \mathrm{H}_{17} \mathrm{ClN}_{6} \mathrm{O}_{2} \mathrm{~S}$ (488.95) C, 58.95; H, 3.50; N, 17.19. Found: C, 58.76; H, 3.41; $\mathrm{N}, 17.06 \%$.

\section{7-(4-Benzenesulfonyl-phenyl)-3-m-tolylazo-pyrazolo[1,5-a]pyrimidin-2-ylamine (13b)}

Red solid, mp.: $235-237^{\circ} \mathrm{C}(\mathrm{AcOH}), \mathrm{IR} v$ : 3421, $3274\left(\mathrm{NH}_{2}\right), 3165\left(\mathrm{sp}^{2}-\mathrm{CH}\right), 2919$ (sp $\left.{ }^{3}-\mathrm{CH}\right), 1616$ $(\mathrm{C}=\mathrm{N}) \mathrm{cm}^{-1} ;{ }^{1} \mathrm{H}$ NMR (DMSO-d 6 ) $\delta: 2.39\left(\mathrm{~s}, 3 \mathrm{H}, \mathrm{CH}_{3}\right), 7.18(\mathrm{~d}, J=7.65 \mathrm{~Hz}, 2 \mathrm{H}, \mathrm{Ar}-\mathrm{H}), 7.25\left(\mathrm{~s}, 2 \mathrm{H}, \mathrm{NH}_{2}\right)$, $7.27(\mathrm{~d}, J=5.1 \mathrm{~Hz}, 1 \mathrm{H}$, Pyrimidine-H), $7.37(\mathrm{t}, J=7.65 \mathrm{~Hz}, 2 \mathrm{H}, \mathrm{Ar}-\mathrm{H}), 7.62(\mathrm{~d}, J=7.65 \mathrm{~Hz}, 1 \mathrm{H}, \mathrm{Ar}-\mathrm{H})$, $7.64(\mathrm{~s}, 1 \mathrm{H}, \mathrm{Ar}-\mathrm{H}), 7.69(\mathrm{t}, J=7.65 \mathrm{~Hz}, 1 \mathrm{H}, \mathrm{Ar}-\mathrm{H}), 7.75(\mathrm{t}, J=7.65 \mathrm{~Hz}, 1 \mathrm{H}, \mathrm{Ar}-\mathrm{H}), 8.06(\mathrm{~d}, J=7.65 \mathrm{~Hz}$, $1 \mathrm{H}, \mathrm{Ar}-\mathrm{H}), 8.18(\mathrm{~d}, J=7.65 \mathrm{~Hz}, 2 \mathrm{H}, \mathrm{Ar}-\mathrm{H}), 8.23(\mathrm{~d}, J=7.65 \mathrm{~Hz}, 2 \mathrm{H}, \mathrm{Ar}-\mathrm{H}), 8.63(\mathrm{~d}, J=5.1 \mathrm{~Hz}, 1 \mathrm{H}$, Pyrimidine-H). ${ }^{13} \mathrm{C}$ NMR (DMSO- $\left.d_{6}\right) \delta: 20.9\left(\mathrm{CH}_{3}\right), 109.5,114.6,118.9,120.5,121.2,127.3,127.6,128.8$, 129.3, 129.9, 134.0, 135.2, 138.4, 140.6, 142.9, 143.3, 147.5, 150.6, 151.8, 152.9. Ms $m / z(\%) 468\left(\mathrm{M}^{+}, 8\right)$, 454 (14), 395 (11), 377 (15), 311 (12), 250 (7), 215 (7), 171 (74), 142 (2), 91 (14), 81 (100). Anal. Calcd. For: $\mathrm{C}_{25} \mathrm{H}_{20} \mathrm{~N}_{6} \mathrm{O}_{2} \mathrm{~S}(468.53) \mathrm{C}, 64.09 ; \mathrm{H}, 4.30 ; \mathrm{N}, 17.94$. Found: $\mathrm{C}, 63.89 ; \mathrm{H}, 4.21 ; \mathrm{N}, 17.85 \%$.

\section{7-(4-Benzenesulfonyl-phenyl)-3-(3-chloro-phenylazo)- pyrazolo[1,5-a]pyrimidin-2-ylamine (13c)}

Red crystals, mp.: $245-247^{\circ} \mathrm{C}(\mathrm{AcOH}), \mathrm{IR} v$ : 3421, $3274\left(\mathrm{NH}_{2}\right), 3067\left(\mathrm{sp}^{2}-\mathrm{CH}\right), 1616(\mathrm{C}=\mathrm{N}) \mathrm{cm}^{-1}$; ${ }^{1} \mathrm{H}$ NMR (DMSO- $\left.d_{6}\right) \delta: 7.26-8.23\left(\mathrm{~m}, 16 \mathrm{H}, \mathrm{Ar}-\mathrm{H}\right.$ and $\left.\mathrm{NH}_{2}\right), 8.61(\mathrm{~d}, J=4.5 \mathrm{~Hz}, 1 \mathrm{H}$, pyrimidine- $\mathrm{H})$. ${ }^{13} \mathrm{C}$ NMR (DMSO- $d_{6}$ ) $\delta: 110.0,115.1,120.2,120.3,127.3,127.6,127.8,129.9,130.5,130.9,133.8,134.0$, 135.1, 140.6, 142.9, 143.4, 147.7, 150.9, 151.9, and 154.2. Ms $m / z(\%) 488\left(\mathrm{M}^{+}, 8\right), 458$ (19), 412 (19), 377 (11), 273 (44), 249 (100), 218(7), 161 (14), 143 (37), 111 (59), and 108 (74). Anal. Calcd. For: $\mathrm{C}_{24} \mathrm{H}_{17} \mathrm{ClN}_{6} \mathrm{O}_{2} \mathrm{~S}$ (488.95) C, 58.95; H, 3.50; N, 17.19. Found: C, 58.88; H, 3.41; N, 17.01\%.

\section{7-(4-Benzenesulfonyl-phenyl)-3-(2-chloro-phenylazo)- pyrazolo[1,5-a]pyrimidin-2-ylamine (13d)}

Orange crystals, mp.: $280-282{ }^{\circ} \mathrm{C}(\mathrm{AcOH}), \mathrm{IR} v$ : 3398, $3298\left(\mathrm{NH}_{2}\right), 3164\left(\mathrm{sp}^{2}-\mathrm{CH}\right), 2997\left(\mathrm{sp}^{3}-\mathrm{CH}\right)$, $1615(\mathrm{C}=\mathrm{N}) \mathrm{cm}^{-1} ;{ }^{1} \mathrm{H}$ NMR (DMSO- $\left.d_{6}\right) \delta: 7.32\left(\mathrm{~d}, J=4 \mathrm{~Hz}, 1 \mathrm{H}\right.$, pyrimidine-H), $7.46\left(\mathrm{~s}, 2 \mathrm{H}, \mathrm{NH}_{2}\right)$, 7.67-8.24 $(\mathrm{m}, 13 \mathrm{H}, \mathrm{Ar}-\mathrm{H})$, and $8.66\left(\mathrm{~d}, J=4 \mathrm{~Hz}, 1 \mathrm{H}\right.$, pyrimidine-H). ${ }^{13} \mathrm{C}$ NMR (DMSO- $\left.d_{6}\right) \delta: 110.6$, 116.4, 116.43, 127.4, 127.7, 128.0, 129.8, 130.0, 130.3, 131.1, 131.5, 134.2, 135.1, 140.6, 143.0, 143.8, 147.8, 148.2, 151.3, and 151.9. Ms m/z (\%) $488\left(\mathrm{M}^{+}, 8\right), 452$ (13), 411 (100), 378 (28), 364 (20), 272 (30), 254 (17), 213 (25), 111 (26), and 90 (27). Anal. Calcd. For: $\mathrm{C}_{24} \mathrm{H}_{17} \mathrm{ClN}_{6} \mathrm{O}_{2} \mathrm{~S}$ (488.95) C, 58.95; H, 3.50; N, 17.19. Found: C, 58.82; H, 3.34; N, 17.06\%. 


\section{7-(4-Benzenesulfonyl-phenyl)-3-(3-methoxy-phenylazo)- pyrazolo[1,5-a]pyrimidin-2-ylamine (13e)}

Red solid, mp.: 258-260 ${ }^{\circ} \mathrm{C}(\mathrm{AcOH}), \mathrm{IR}$ v́: 3437, $3298\left(\mathrm{NH}_{2}\right), 3155\left(\mathrm{sp}^{2}-\mathrm{CH}\right), 2909$ (sp $\left.{ }^{3}-\mathrm{CH}\right), 1612$ $(\mathrm{C}=\mathrm{N}) \mathrm{cm}^{-1} ;{ }^{1} \mathrm{H}$ NMR $\left(\mathrm{DMSO}-d_{6}\right) \delta: 3.83\left(\mathrm{~s}, 3 \mathrm{H}, \mathrm{OCH}_{3}\right), 6.94-6.95(\mathrm{~m}, 1 \mathrm{H}, \mathrm{Ar}-\mathrm{H}), 7.27\left(\mathrm{~s}, 2 \mathrm{H}, \mathrm{NH}_{2}\right)$, $7.29(\mathrm{~d}, J=4.5 \mathrm{~Hz}, 1 \mathrm{H}$, pyrimidine-H), 7.39-7.44 (m, 3H, Ar-H), $7.68(\mathrm{t}, J=7.65 \mathrm{~Hz}, 2 \mathrm{H}, \mathrm{Ar}-\mathrm{H}), 7.74$ $(\mathrm{t}, J=6.8 \mathrm{~Hz}, 1 \mathrm{H}, \mathrm{Ar}-\mathrm{H}), 8.06(\mathrm{~d}, J=7.65 \mathrm{~Hz}, 2 \mathrm{H}, \mathrm{Ar}-\mathrm{H}), 8.18(\mathrm{~d}, J=8.5 \mathrm{~Hz}, 2 \mathrm{H}, \mathrm{Ar}-\mathrm{H}), 8.23(\mathrm{~d}, J=8.5$ $\mathrm{Hz}, 2 \mathrm{H}, \mathrm{Ar}-\mathrm{H}$ ), and $8.64\left(\mathrm{~d}, J=4.5 \mathrm{~Hz}, 1 \mathrm{H}\right.$, pyrimidine-H). ${ }^{13} \mathrm{C}$ NMR (DMSO- $\left.d_{6}\right) \delta: 55.2,105.5,109.6$, 114.1, 114.6, 114.9, 127.3, 127.6, 129.7, 129.9, 130.9, 134.0, 135.2, 140.6, 142.9, 143.3, 147.5, 150.7, 151.9, 154.2, and 160.0. Ms $m / z(\%) 484\left(\mathrm{M}^{+}, 15\right), 454$ (24), 407 (11), 379 (17), 360 (100), 349 (12), 327 (10), 267 (7), 218 (15), 160 (7), 136 (41), and 78(17). Anal. Calcd. For: $\mathrm{C}_{25} \mathrm{H}_{20} \mathrm{~N}_{6} \mathrm{O}_{3} \mathrm{~S}(484.53) \mathrm{C}, 61.97 ; \mathrm{H}, 4.16 ; \mathrm{N}$, 17.34. Found: C, $61.76 ; \mathrm{H}, 4.00 ; \mathrm{N}, 17.15 \%$.

\section{7-(4-Benzenesulfonyl-phenyl)-3-phenylazo- pyrazolo[1,5-a]pyrimidin-2-ylamine (13f)}

Red solid, mp.: $215-217^{\circ} \mathrm{C}(\mathrm{AcOH}), \mathrm{IR}$ v́: 3420, $3270\left(\mathrm{NH}_{2}\right), 3162\left(\mathrm{sp}^{2}-\mathrm{CH}\right), 2998$ (sp $\left.{ }^{3}-\mathrm{CH}\right), 1616$ $(\mathrm{C}=\mathrm{N}) \mathrm{cm}^{-1} ;{ }^{1} \mathrm{H}$ NMR $\left(\mathrm{DMSO}-d_{6}\right) \delta: 7.22-8.24\left(\mathrm{~m}, 17 \mathrm{H}, \mathrm{Ar}-\mathrm{H}\right.$ and $\left.\mathrm{NH}_{2}\right), 8.60(\mathrm{~d}, J=4.5 \mathrm{~Hz}, 1 \mathrm{H}$, pyrimidine-H). ${ }^{13} \mathrm{C}$ NMR (DMSO- $d_{6}$ ) $\delta: 114.7,121.1,127.3,127.6,129.0,129.2,129.9,130.9,131.1,134.0$, 135.1, 140.6, 142.9, 143.3, 147.5, 150.6, 151.8, and 152.9. Ms $\mathrm{m} / \mathrm{z}(\%) 454\left(\mathrm{M}^{+}, 19\right), 438(27), 364$ (7), 361 (27), 349 (16), 313 (14), 237 (10), 217 (14), 208 (27), and 106 (100). Anal. Calcd. For: $\mathrm{C}_{24} \mathrm{H}_{18} \mathrm{~N}_{6} \mathrm{O}_{2} \mathrm{~S}$ (454.50) C, 63.42; H, 3.99; N, 18.49. Found: C, 63.32; H, 3.88; N, 18.32\%.

\section{7-(4-Benzenesulfonyl-phenyl)-3-(2-nitro-phenylazo)-pyrazolo[1,5-a]pyrimidin-2-ylamineylamine (13g)}

Red solid, mp.: 265-267 ${ }^{\circ} \mathrm{C}(\mathrm{AcOH}), \mathrm{IR} v$ : 3410, $3294\left(\mathrm{NH}_{2}\right), 3165$ (sp $\left.2-\mathrm{CH}\right), 2900\left(\mathrm{sp}^{3}-\mathrm{CH}\right), 1617$ $(\mathrm{C}=\mathrm{N}) \mathrm{cm}^{-1} ;{ }^{1} \mathrm{H}$ NMR (DMSO- $\left.d_{6}\right) \delta: 7.46(\mathrm{~d}, J=4.5 \mathrm{~Hz}, 1 \mathrm{H}$, pyrimidine- $\mathrm{H}), 7.60(\mathrm{t}, J=7 \mathrm{~Hz}, 1 \mathrm{H}, \mathrm{Ar}-\mathrm{H})$, 7.73-7.83 (m, 6H, Ar-H and $\left.\mathrm{NH}_{2}\right), 7.95(\mathrm{dd}, J=8,1.7 \mathrm{~Hz}, 1 \mathrm{H}, \mathrm{Ar}-\mathrm{H}), 8.05(\mathrm{dd}, J=8,1.7 \mathrm{~Hz}, 1 \mathrm{H}, \mathrm{Ar}-\mathrm{H})$, $8.11(\mathrm{dd}, J=8,1.7 \mathrm{~Hz}, 2 \mathrm{H}, \mathrm{Ar}-\mathrm{H}), 8.24(\mathrm{~d}, J=8.5 \mathrm{~Hz}, 2 \mathrm{H}, \mathrm{Ar}-\mathrm{H}), 8.27(\mathrm{~d}, J=8.5 \mathrm{~Hz}, 2 \mathrm{H}, \mathrm{Ar}-\mathrm{H})$, and 8.76 (d, $J=4.5 \mathrm{~Hz}, 1 \mathrm{H}$, pyrimidine-H). Ms $m / z(\%) 499\left(\mathrm{M}^{+}, 58\right), 453$ (11), 422 (28), 378 (27), 362 (5), 218 (6), 208 (100), 151(11), 142 (5), 122 (10), and 77 (30). Anal. Calcd. For: $\mathrm{C}_{24} \mathrm{H}_{17} \mathrm{~N}_{7} \mathrm{O}_{4} \mathrm{~S}$ (499.50) C, 57.71; H, 3.43 ; N, 19.63. Found: C, 57.56; H, 3.40; N, 19.52\%.

\section{7-(4-Benzenesulfonyl-phenyl)-3-(4-methoxy-phenylazo)- pyrazolo[1,5-a]pyrimidin-2-ylamine (13h)}

Red, yield (94\%), mp.: 255-257 ${ }^{\circ} \mathrm{C}(\mathrm{AcOH}), \mathrm{IR} v$ : 3447, $3337\left(\mathrm{NH}_{2}\right), 3066\left(\mathrm{sp}^{2}-\mathrm{CH}\right), 2900\left(\mathrm{sp}^{3}-\mathrm{CH}\right)$, $1611(\mathrm{C}=\mathrm{N}) \mathrm{cm}^{-1} ;{ }^{1} \mathrm{H}$ NMR (DMSO-d 6 ) $\delta: 3.83\left(\mathrm{~s}, 3 \mathrm{H}, \mathrm{OCH}_{3}\right), 7.06(\mathrm{~d}, J=8.5 \mathrm{~Hz}, 2 \mathrm{H}, \mathrm{Ar}-\mathrm{H}), 7.17(\mathrm{~s}, 2 \mathrm{H}$, $\left.\mathrm{NH}_{2}\right), 7.24(\mathrm{~d}, J=5.1 \mathrm{~Hz}, 1 \mathrm{H}$, pyrimidine-H), $7.68(\mathrm{t}, J=7.65 \mathrm{~Hz}, 2 \mathrm{H}, \mathrm{Ar}-\mathrm{H}), 7.74(\mathrm{t}, J=7.65 \mathrm{~Hz}, 1 \mathrm{H}$, Ar-H), $7.81(\mathrm{~d}, J=8.5 \mathrm{~Hz}, 2 \mathrm{H}, \mathrm{Ar}-\mathrm{H}), 8.06(\mathrm{~d}, J=8.5 \mathrm{~Hz}, 2 \mathrm{H}, \mathrm{Ar}-\mathrm{H}), 8.18(\mathrm{~d}, J=8.5 \mathrm{~Hz}, 2 \mathrm{H}, \mathrm{Ar}-\mathrm{H}), 8.23$ $(\mathrm{d}, J=8.5 \mathrm{~Hz}, 2 \mathrm{H}, \mathrm{Ar}-\mathrm{H})$, and $8.61\left(\mathrm{~d}, J=4.5 \mathrm{~Hz}, 1 \mathrm{H}\right.$, pyrimidine-H). ${ }^{13} \mathrm{C}$ NMR (DMSO- $\left.d_{6}\right) \delta: 55.4,109.1$, 114.1, 114.3, 122.6, 127.3, 127.6, 129.9, 130.8, 134.0, 135.3, 140.6, 142.9, 143.2, 147.1, 147.2, 150.4, 151.9, 159.9. Ms $m / z(\%) 484\left(\mathrm{M}^{+}, 22\right), 454$ (16), 406 (23), 377 (24), 351 (90), 327 (22), 251 (50), 134(5), 124 (43), 105 (19), and 58 (100). Anal. Calcd. For: $\mathrm{C}_{25} \mathrm{H}_{20} \mathrm{~N}_{6} \mathrm{O}_{3} \mathrm{~S}(484.53) \mathrm{C}, 61.97 ; \mathrm{H}, 4.16 ; \mathrm{N}, 17.34$. Found: $\mathrm{C}$, $61.78 ; \mathrm{H}, 4.03 ; \mathrm{N}, 17.25 \%$.

\subsection{Biological Methods}

Antimicrobial Activity Test

The antimicrobial activity of the synthesized compounds have been determined using the agar diffusion well method which is a suitable for such biological activity measurement. Culture collection of the Regional Center for Mycology and Biotechnology (RCMB), Al-Azhar University, Cairo, Egypt provided all strains in this study. For fungi, the microbes' inoculums were spread using sterile cotton swab with uniform manner on a sterile petri dish malt extract agar. In case of bacteria, the microbes' inoculums were spread on the nutrient agar. $100 \mu \mathrm{L}$ of a given sample was added to each well which is ten $\mathrm{mm}$ diameter holes cut in the agar gel, twenty $\mathrm{mm}$ apart from each other). All systems prepared were incubated for $1-2$ days at $37^{\circ} \mathrm{C}$ for antibacterial activity measurements and at a temperature 
of $28^{\circ} \mathrm{C}$ for antifungal measurements. The microorganism's growth was observed after the latter incubation. The inhibition zone of the bacterial and fungal growth have been measured as IZD in millimeter. Finally, all the mentioned tests were performed in triplicate for all compounds.

In case of estimation the MIC of the examined samples, micro-dilution test was performed in 96-well plates. Two-fold dilutions of each sample were prepared in the test wells, the final drug concentrations being $(125-0.004) \mu \mathrm{g} / \mathrm{mL}$, control wells were prepared with culture medium only and microbial suspension only. The plates were sealed and incubated for $24 \mathrm{~h}$ at $37^{\circ} \mathrm{C}$ for bacteria and for $48 \mathrm{~h}$ at $28^{\circ} \mathrm{C}$ for fungi, after each incubation time, MIC was detected as the lowest sample concentration that prevented microbial growth. Each MIC was determined three times.

\section{Conclusions}

In conclusion, we have synthesized new series of pyrazolo[1,5-a]pyrimidine derivatives incorporated phenylsulfonyl and arylazo moieties using a simple methodology. The synthetic methodology included the use of conventional heating and microwaves irradiation under pressurized conditions in a safe manner. The antimicrobial activities of novel compounds are evaluated and three compounds 13c, $\mathbf{1 3 d}$, and $\mathbf{1 3} \mathrm{g}$ demonstrated the highest antibacterial activity against all Gram-positive and -negative bacteria. Other sulfone derivatives showed fair to low antibacterial and antifungal activities. In general, derivatives containing one phenylsulfonyl group are more effective against all most antibacterial and antifungal species used than that contain two phenylsulfonyl groups.

Author Contributions: M.R.S. Conceived and designed the experiments, analyzed and interpreted the data, contributed reagents and materials, and wrote the paper. T.A.F. Conceived and designed the experiments, analyzed and interpreted the data, and wrote the paper. A.M.R.A. Performed the experiments, analyzed, and interpreted the data.

Funding: All authors would like to thank Deanship of Scientific Research at Umm Al-Qura University for supporting this work (Project code: 18-SCI-5-06-0005).

Conflicts of Interest: The authors declare no conflict of interest.

\section{References}

1. Novinson, T.; Bhooshan, B.; Okabe, T.; Revankar, G.R.; Robins, R.K.; Senga, K.; Wilson, H.R. Novel heterocyclic nitrofurfural hydrazones. In vivo antitrypanosomal activity. J. Med. Chem. 1976, 19, 512-516. [CrossRef]

2. Fraley, M.E.; Rubino, R.S.; Hoffman, W.F.; Hambaugh, S.R.; Arrington, K.L.; Hungate, R.W.; Bilodeau, M.T.; Tebben, A.J.; Rutledge, R.Z.; Kendall, R.L.; et al. Optimization of a pyrazolo [1,5-a]pyrimidine class of KDR kinase inhibitors: Improvements in physical properties enhance cellular activity and pharmacokinetics. Bioorg. Med. Chem. Lett. 2002, 12, 3537-3541. [CrossRef]

3. Selleri, S.; Bruni, F.; Costagli, C.; Costanzo, A.; Guerrini, G.; Ciciani, G.; Gratteri, P.; Besnard, F.; Costa, B.; Montali, M.; et al. A novel selective GABAA a1 receptor agonist displaying sedative and anxiolytic-like properties in rodents. J. Med. Chem. 2005, 48, 6756-6760. [CrossRef]

4. Selleri, S.; Bruni, F.; Costagli, C.; Costanzo, A.; Guerrini, G.; Ciciani, G.; Costa, B.; Martini, C. 2-Arylpyrazolo[1,5-a]pyrimidin-3-yl acetamides. New potent and selective peripheral benzodiazepine receptor ligands. Bioorg. Med. Chem. 2001, 9, 2661-2671. [CrossRef]

5. Novinson, T.; Hanson, R.; Dimmitt, M.K.; Simon, L.N.; Robins, R.K.; O’Brien, D.E. 3-Substituted 5,7-dimethylpyrazolo[1,5-a]pyrimidines, 3'5'-cyclic AMP phosphor-diesterase inhibitors. J. Med. Chem. 1974, 17, 645-648. [CrossRef] [PubMed]

6. Suzuki, M.; Iwasaki, H.; Fujikawa, Y.; Sakashita, M.; Kitahara, M.; Sakoda, R. Synthesis and biological evaluations of condensed pyridine and condensed pyrimidine-based HMG-CoA reductase inhibitors. Bioorg. Med. Chem. Lett. 2001, 11, 1285-1288. [CrossRef]

7. Almansa, C.; De Arriba, A.F.; Cavalcanti, F.L.; Gomez, L.A.; Miralles, A.; Merlos, M.; Garcia-Rafanell, J.; Forn, J. Synthesis and SAR of a new series of COX-2-selective inhibitors: Pyrazolo[1,5-a]pyrimidines. J. Med. Chem. 2001, 44, 350-361. [CrossRef] 
8. Hwang, J.Y.; Windisch, M.P.; Jo, S.; Kim, K.; Kong, S.; Kim, H.C.; Kim, S.; Kim, H.; Lee, M.E.; Kim, Y.; et al. Discovery and characterization of a novel 7-aminopyrazolo[1,5-a]pyrimidine analog as a potent hepatitis C virus inhibitor. Bioorg. Med. Chem. Lett. 2012, 22, 7297-7301. [CrossRef] [PubMed]

9. Ivachtchenko, A.V.; Dmitriev, D.E.; Golovina, E.S.; Kadieva, M.G.; Koryakova, A.G.; Kysil, V.M.; Mitkin, O.D.; Okun, I.M.; Tkachenko, S.E.; Vorobiev, A.A. (3-Phenylsulfonylcycloalkano[e and d]pyrazolo[1,5-a]pyrimidin-2-yl)amines: Potent and selective antagonists of the serotonin 5-HT6 receptor. J. Med. Chem. 2010, 53, 5186-5196. [CrossRef] [PubMed]

10. Xu, J.; Liu, H.; Li, G.; He, Y.; Ding, R.; Wang, X.; Feng, M.; Zhang, S.; Chen, Y.; Li, S.; et al. Synthesis and biological evaluation of 7-(2-chlorophenyl- amino)-5-((2-[18F]fluoro-ethyoxy)methyl)pyrazolo[1,5-a]pyrimidine3-carbonitrile as PET tumor imaging agent. Z. Naturforsch. B. Chem. Sci. 2012, 67, 827-834. [CrossRef]

11. Hanan, E.J.; Abbema, A.V.; Barrett, K.; Blair, W.S.; Blaney, J.; Chang, C.; Eigenbrot, C.; Flynn, S.; Gibbons, P.; Hurley, C.A.; et al. Discovery of potent and selective pyrazolopyrimidine Janus kinase 2 inhibitors. J. Med. Chem. 2012, 55, 10090-10107. [CrossRef] [PubMed]

12. Saito, T.; Obitsu, T.; Kondo, T.; Matsui, T.; Nagao, Y.; Kusumi, K.; Matsumura, N.; Ueno, S.; Kishi, A.; Katsumata, S.; et al. 6,7-Dihydro-5H-cyclopenta[d]pyrazolo[1,5-a]pyrimidines and their derivatives as novel corticotropin-releasing factor 1 receptor antagonists. Bioorg. Med. Chem. 2011, 19, 5432-5445. [CrossRef] [PubMed]

13. Tian, Y.; Du, D.; Rai, D.; Wang, L.; Liu, H.; Zhan, P.; Clercq, C.; Pannecouque, E.D.; Liu, X. Fused heterocyclic compounds bearing bridgehead nitrogen as potent HIV-1 NNRTIs. Part 1: Design, synthesis and biological evaluation of novel 5,7-disubstituted pyrazolo[1,5-a]pyrimidine derivatives. Bioorg. Med. Chem. 2014, 22, 2052-2059. [CrossRef] [PubMed]

14. Ishak, C.Y.; Metwally, N.H.; Wahbi, H.I. In vitro antimicrobial and antifungal activity of pyrimidine and pyrazolo[1,5-a]pyrimidine. Int. J. Pharm. Phytopharm. Res. 2013, 2, 407-411.

15. Cherukupalli, S.; Karpoormath, R.; Chandrasekaran, B.; Hampannavar, G.A.; Thapliyal, N.; Palakollu, V.N. An insight on synthetic and medicinal aspects of pyrazolo[1,5-a] pyrimidine scaffold. Eur. J. Med. Chem. 2017, 126, 298-352. [CrossRef]

16. Teall, M.; Oakley, P.; Harrison, T.; Shaw, D.; Kay, E.; Elliott, J.; Gerhard, U.; Castro, J.L.; Shearman, M.; Ball, R.G.; et al. Aryl sulfones: A new class of $\gamma$-secretase inhibitors. Bioorg. Med. Chem. Lett. 2005, 15, 2685-2688. [CrossRef]

17. Tfelt-Hansen, P.; De Vries, P.; Saxena, P.R. Triptans in migraine: A comparative review of pharmacology, pharmacokinetics and efficacy. Drugs 2000, 60, 1259-1287. [CrossRef]

18. Chung, K.-T. Azo dyes and human health: A review. J. Environ. Sci. Health C Environ. Carcinog. Ecotoxicol. Rev. 2016, 34, 233-261. [CrossRef]

19. Walker, R. Metabolism of azo group: A review of literature. Food Cosmet. Toxicol. 1970, 8, 659-676. [CrossRef]

20. Moanta, A.; Radu, S. Spectroscopic analysis and antimicrobial activity of some 4-phenylazo-phenoxyacetic acids. Rev. Roum. Chem. 2009, 54, 151-156.

21. Garjani, A.; Davaran, S.; Rashidi, M.; Malek, N. Protective effects of some azo derivatives of 5-aminosalicylic acid and their pegylated prodrugs on acetic acid-induced rat colitis. DARU J. Pharm. Sci. 2004, 12, 24-30.

22. Concilio, S.; Sessa, L.; Petrone, A.M.; Porta, A.; Diana, R.; Iannelli, P.; Piotto, S. Structure Modification of an Active Azo-Compound as a Route to New Antimicrobial Compounds. Molecules 2017, 22, 875. [CrossRef] [PubMed]

23. Sessa, L.; Concilio, S.; Iannelli, P.; De Santis, F.; Porta, A.; Piotto, S. Antimicrobial azobenzene compounds and their potential use in biomaterials. AIP Conf. Proc. 2016, 1727, 020018.

24. Viegas-Junior, C.; Danuello, A.; Bolzani, V.S.; Barreiro, E.J.; Fraga, C.A.M. Molecular Hybridization: A Useful Tool in the Design of New Drug Prototypes. Curr. Med. Chem. 2007, 14, 1829-1852. [CrossRef]

25. Amin, M.M.; Shaaban, M.R.; Al-Qurashi, N.T.; Mahmoud, H.K.; Farghaly, T.A. Indomethacin Analogs: Synthesis, Anti-inflammatory and Analgesic Activities of Indoline Derivatives. Mini-Rev. Med. Chem. 2018, 18, 1409-1421. [CrossRef]

26. Farghaly, T.A.; Abdallah, M.A.; Masaret, G.S.; Muhammad, Z.A. New and efficient approach for synthesis of novel bioactive [1,3,4]thiadiazoles incorporated with 1,3-thiazole moiety. Eur. J. Med. Chem. 2015, 320-333. [CrossRef] 
27. Althagafi, I.I.; Abouzied, A.S.; Farghaly, T.A.; Al-Qurashi, N.T.; Alfaifi, M.Y.; Shaaban, M.R.; Abdel Azizd, M.R. Novel Nano-sized bis-indoline Derivatives as Antitumor Agents. J. Heterocycl. Chem. 2019, 56, 391-399. [CrossRef]

28. Salem, M.E.; Darweesh, A.F.; Shaaban, M.R.; Elwahy, A.H.M. Synthesis of novel bis- and poly(hydrazinylthiazole) linked to benzofuran or benzothiazole as new hybrid molecules. Arkivoc 2019, v, 73-88. [CrossRef]

29. Alsharekh, M.M.; Althagafi, I.I.; Shaaban, M.R.; Farghaly, T.A. Microwave assisted and thermal synthesis of nanosized thiazolyl-phenothiazine derivatives and their biological activities. Res. Chem. Inter. 2019, 45, 127-154. [CrossRef]

30. Shaaban, M.R.; Saleh, T.S.; Farag, A.M. Synthesis and antimicrobial evaluation of novel pyrazolo [1,5-a] pyrimidine, triazolo[1,5-a] pyrimidineand pyrimido [1,2-a] benzimidazole derivatives. Heterocycles 2007, 71 , 1765-1777.

31. Shaaban, M.R.; Saleh, T.S.; Mayhoub, A.S.; Mansour, A.; Farag, A.M. Synthesis and analgesic/anti-inflammatory evaluation of fused heterocyclic ring systems incorporating phenylsulfonyl moiety. Bioorg. Med. Chem. 2008, 16, 6344-6452. [CrossRef] [PubMed]

32. Farghaly, T.A.; Abdel Hafez, N.A.; Ragab, E.A.; Awad, H.M.; Abdalla, M.M. Synthesis, anti-HCV, antioxidant, and peroxynitrite inhibitory activity of fused benzosuberone derivatives. Eur. J. Med. Chem. 2010, 45, 492-500. [CrossRef] [PubMed]

33. Bennett, P.; Donnelly, J.A.; Meaney, D.C.; Boyle, P.O. Stereochemistry of cyclopropyl ketones from the reaction of dimethylsulphoxonium methylide with 3-benzylidenechroman-4-ones. J. Chem. Soc. Perkin Trans. I 1972, 1554-1559. [CrossRef]

34. Dawood, D.H.; Abbas, E.M.H.; Farghaly, T.A.; Ali, M.M.; Ibrahim, M.F. ZnO Nanoparticles catalyst in Synthesis of Bioactive Fused Pyrimidines as Anti-breast Cancer Agents Targeting VEGFR-2. Med. Chem. 2019, 15, 277-286. [CrossRef]

35. Shaaban, M.R.; Saleh, T.S.; Mayhoube, A.S.; Farag, A.M. Single step synthesis of new fused pyrimidine derivatives and their evaluation as potent Aurora-A kinase inhibitors. Eur. J. Med. Chem. 2011, 46, 3690-3695. [CrossRef]

36. Selleri, S.; Bruni, F.; Costagli, C.; Costanzo, A.; Guerrini, G.; Ciciani, G.; Costa, B.; Martini, C. Synthesis and BZR Affnity of Pyrazolo[1,5-a]pyrimidine Derivatives. Part 1: Study of the Structural Features for BZR Recognition. Bioorg. Med. Chem. 1999, 7, 2705-2711. [CrossRef]

Sample Availability: Samples of the compounds $\mathbf{8 a}-\mathbf{h}$ and $\mathbf{1 3} \mathbf{a}-\mathbf{h}$ are available from the authors.

(C) 2019 by the authors. Licensee MDPI, Basel, Switzerland. This article is an open access article distributed under the terms and conditions of the Creative Commons Attribution (CC BY) license (http://creativecommons.org/licenses/by/4.0/). 